\title{
MODEL MEDIASI DAN MODERASI DALAM HUBUNGAN ANTARA PERILAKU POLITIK PIMPINAN, KOMPETENSI AUDITOR, DAN KINERJA AUDITOR
}

\author{
Didi \\ didi.juniardy@yahoo.co.id \\ Program Pascasarjana Ilmu Akuntansi Fakultas Ekonomi dan Bisnis \\ Universitas Pancasila (UP) Jakarta
}

\begin{abstract}
This study aims to examine how the political behavior of the leadership of the directorate can reduce auditor competence and how political behavior can weaken auditor competency, which in turn both reduce auditor performance. To explain these two things, in this study two models were proposed, namely: the leadership model of political behavior after being edited by auditor competence and its impact on auditor performance and auditor competency models after being moderated by political behavior and its impact on auditor performance. The research method used is the survey method, namely: the research method that collects data by distributing questionnaires to the sample used as respondents. The sampling technique was proportionate stratified random sampling, so that from 461 auditors who were the population of 27 District or City Inspectorates in West Java 210 respondents were to be sampled. The analytical tool uses Component Based Structural Equation Modeling (CBSEM) with the help of software SmartPLS version 3.0. The results of the study prove that: the political behavior of the leadership after being moderated by competence has a significant negative effect on auditor performance, and the leadership's political behavior after moderating auditor competency has a significant negative effect on auditor performance.
\end{abstract}

Key words: leadership political behavior; auditor competency; and auditor performance

\begin{abstract}
ABSTRAK
Penelitian ini bertujuan untuk meneliti bagaimana perilaku politik pimpinan inspektorat dapat menurunkan kompetensi auditor dan bagaimana perilaku politik dapat memperlemah kompetensi auditor, yang pada akhirnya kedua hal tersebut menurunkan kinerja auditor. Untuk menjelaskan kedua hal tersebut, dalam penelitian ini diajukan dua model, yaitu: model perilaku politik pimpinan setelah dimediasi oleh kompetensi auditor serta dampaknya terhadap kinerja auditor dan model kompetensi auditor setelah dimoderasi oleh perilaku politik serta dampaknya terhadap kinerja auditor. Metode penelitian yang digunakan adalah metode survei, yaitu: metode penelitian yang mengumpulkan data dengan cara menyebarkan kuesioner kepada sampel yang dijadikan responden. Teknik pengambilan sampel proportionate stratafied random sampling, sehingga dari 461 auditor yang menjadi populasi pada 27 Inspektorat Kabupaten atau Kota di Jawa Barat diperoleh 210 responden yang akan dijadikan sampel. Alat analisis menggunakan Component Based Structural Equation Modeling (CBSEM) dengan bantuan software SmartPLS versi 3.0. Hasil penelitian membuktikan bahwa: perilaku politik pimpinan setelah dimediasi oleh kompetensi berpengaruh signifikan negatif terhadap kinerja auditor, dan perilaku politik pimpinan setelah memoderasi kompetensi auditor berpengaruh signifikan negatif terhadap kinerja auditor.
\end{abstract}

Kata kunci: perilaku politik pimpinan; kompetensi auditor; dan kinerja auditor

\section{PENDAHLUAN}

Menurut data yang dipublikasikan Komisi Pemberantasan Korupsi (KPK) dalam kurun waktu empat belas tahun sejak diberlakukannya undang-undang otonomi daerah, terdapat lima provinsi yang paling banyak terjadi perkara tindak pidana korupsi (tipikor), yaitu: Provinsi Jawa Timur 
sebanyak 75 perkara, Provinsi Jawa Barat sebanyak 66 perkara, Provinsi Sumatera Utara sebanyak 57 perkara, Provinsi DKI Jakarta sebanyak 54 perkara, dan Provinsi Jawa Tengah sebanyak 39 perkara (KPK, 2018). Strategi untuk menekan tindak pidana korupsi yang merugikan keuangan daerah telah lama dilakukan melalui penguatan fungsi inspektorat pada tingkat kabupaten atau kota sebagai early warning system seperti diamanatkan oleh Peraturan Menteri Dalam Negeri No.71 tahun 2015 tentang Kebijakan Pengawasan di Lingkungan Kementerian Dalam Negeri dan Penyelengaraan Pemerintah Daerah.

Namun langkah peningkatan peranan inspektorat tersebut bukanlah sesuatu yang mudah untuk diimplementasikan, masih terdapat banyak faktor yang harus dibenahi seperti: kinerja auditor, kompetensi auditor, dan perilaku anggota maupun pimpinan inspektorat itu sendiri. Usaha-usaha pemerintah untuk meningkatkan kompetensi auditor inspektorat telah lama dilakukan pemerintah melalui mekanisme sertifikasi Jabatan Fungsional Auditor (JFA) yang diatur oleh Peraturan Menteri Pendayagunaan Aparatur Negara No. Per/220/M.PAN/ 7/2008. Melalui mekanisme tersebut, diharapkan masing-masing auditor dapat melaksanakan tugas pokok yang menjadi tanggung jawabnya sesuai dengan kompetensi yang dibutuhkan.

Meskipun pemerintah telah berupaya untuk meningkatkan kompetensi auditor inspektorat, pada kenyataannya kompetensi tersebut tidak dapat meningkatkan kinerja inspektorat yang dibuktikan dengan masih banyaknya tindak pidana korupsi yang terjadi di pemerintahan daerah. Hal ini mengindikasikan adanya theory gap yang berkaitan kompetensi dapat meningkatkan kinerja. Theory gap tersebut didukung dengan research gap, yaitu masih terdapatnya beberapa temuan penelitian yang belum menunjukkan hasil yang konsisten. Penelitian yang dilakukan oleh Permatasari et al. (2016), Andrianti et al. (2016), dan Laana et al. (2015) menemukan kompetensi berpengaruh positif terhadap kinerja auditor pada beberapa inspektorat. Sementara itu, penelitian yang dilakukan oleh Salju et al. (2014) yang meneliti auditor inspektorat Kabupaten Luwu menemukan hal yang sebaliknya, yaitu: kompetensi tidak berpengaruh terhadap kinerja auditor.

Ketidakkonsistenan hasil penelitian tidak hanya ditemukan pada auditor pemerintahan saja, tetapi juga banyak dijumpai pada auditor yang bekerja pada Kantor Akuntan Publik (KAP). Penelitian yang dilakukan Yadnya dan Ariyanto (2017), dan Fernanda (2018) menemukan kompetensi berpengaruh positif terhadap kinerja auditor yang bekerja di KAP. Sementara itu, penelitian yang dilakukan oleh Christina dan Melinda (2012); Wijaya dan Suryadinata (2012) menemukan hal yang sebaliknya, yaitu: kompetensi tidak berpengaruh terhadap kinerja auditor yang bekerja di KAP.

Hal yang sering diabaikan berkaitan dengan upaya peningkatan kinerja adalah aspek perilaku organisasi (organizational behavior). Berkaitan dengan hal itu, salah satu permasalahan yang dikaji dalam aspek perilaku organisasi adalah perilaku politik pimpinan (leadership political behavior). Perilaku politik pimpinan menjadi penting karena pimpinan sebagai "motor penggerak" organisasi yang turut menentukan kelangsungan hidup organisasi. Curtis, 2003 (dalam Jafarani et al. 2012) menekankan pentingnya permasalahan perilaku politik pemimpin karena permasalahan tersebut akan selalu muncul dalam setiap organisasi, serta menjadi permasalahan yang tak terhindarkan. Dampak negatif perilaku politik pemimpin terhadap kinerja telah banyak diteliti di luar negeri, seperti yang dilakukan oleh Bodla, et al. (2014) dan Randall et al. (1999).

Berdasarkan uraian di atas, maka dalam hubungan antara kompetensi, perilaku politik pemimpin, dan kinerja auditor, maka dapat diidentifikasi dua permasalahan sebagai berikut: Pertama, perilaku politik pemimpin dapat menurunkan kompetensi yang dimiliki oleh auditor dan pada 
akhirnya akan diikuti dengan menurunnya kinerja auditor. Kedua, perilaku politik pemimpin dapat memperlemah kompetensi yang pada akhirnya akan diikuti pada menurunnya kinerja auditor.

Oleh karena itu, berkaitan identifikasi permasalahan di atas, maka dapat dirumuskan dua pertanyaan dan rumusan masalah penelitian sebagai berikut: Pertama, apakah perilaku politik pimpinan berpengaruh negatif terhadap kinerja auditor setelah dimediasi dengan kompetensi auditor?. Kedua, apakah kompetensi berpengaruh nega tif terhadap kinerja auditor setelah dimoderasi dengan perilaku politik pimpinan?

Berdasarkan rumusan masalah di atas, maka tujuan penelitian ini adalah untuk: Pertama, membuat pemodelan untuk menguji pengaruh perilaku politik pimpinan terhadap kinerja auditor setelah dimediasi dengan kompetensi auditor. Kedua, membuat pemodelan untuk menguji pengaruh kompetensi auditor terhadap kinerja setelah dimoderasi dengan perilaku politik pimpinan.

\section{TINJAUAN TEORETIS \\ Kinerja Auditor}

Kinerja (performance) merupakan suatu ukuran yang dapat digunakan untuk menetapkan perbandingan hasil pelaksanaan tugas, tanggung jawab yang diberikan oleh organisasi pada periode tertentu dan relatif dapat digunakan untuk mengukur prestasi kerja atau kinerja organisasi (Gibson et al. 1996), sedangkan difinisi kinerja auditor menurut Mulyadi, 1998 (dalam Trisnaningsih, 2007) adalah akuntan publik yang melaksanakan penugasan pemeriksaan (examination) secara obyektif atas laporan keuangan suatu perusahaan atau organisasi lain dengan tujuan untuk menentukan apakah laporan keuangan tersebut menyajikan secara wajar sesuai dengan prinsip akuntansi yang berlaku umum, dalam semua hal yang material, posisi keuangan, dan hasil usaha perusahaan. Berkaitan dengan kinerja, Mangkunegara (2005) membedakan kinerja menjadi dua, yaitu: kinerja individu dan kinerja organisasi. Kinerja individu adalah hasil kerja karyawan baik segi kualitas maupun kuantitas berdasarkan standar yang telah ditentukan, sedangkan kinerja organisasi adalah gabungan dari kinerja individu dengan kinerja kelompok.

Marganingsih dan Martani (2010) mengembangkan model pengukuran kinerja individu auditor dengan memodifikasi komponen kinerja Libby (1995). Menurutnya kinerja individu auditor tidak saja dapat diukur melalui tiga aspek komponen kinerja Libby (1995) seperti: kemampuan, pengetahuan dan pengalaman, tetapi juga terlihat dari ketaatan individu auditor terhadap kode etik.

Berbeda dengan pengukuran kinerja sektor private, pengukuran kinerja inspek torat sebagai salah satu sektor publik mengacu pada Peraturan Menteri Pendayagunaan Aparatur Negara dan Reformasi Birokrasi No.42 tahun 2011 tentang Petunjuk Pelaksanaan Penyusunan Ikhtisar Laporan Hasil Pengawasan Aparat Intern Pemerintahan, kinerja organisasi inspektorat diukur secara kuantitatif atas dua aspek, yaitu: program pengawasan dan hasil pengawasan. Program pengawasan mengukur sejauh mana kegiatan pengawasan yang telah direncanakan yang terdiri atas: audit, review, evaluasi, pemantauan, dan kegiatan pengawasan lain mampu direalisasikan. Sedangkan, hasil pengawasan mengukur sejauh mana auditor dapat melaporkan temuan hasil pengawasannya serta memberikan rekomendasi perbaikan dan tindak lanjut.

\section{Kompetensi Auditor}

Standar Audit Intern Pemerintah Indonesia Sesi 2010 menjelaskan kompetensi sebagai kemampuan profesional yang diperlukan auditor untuk melaksanakan tugas dan tanggung jawabnya. Lebih lanjut standar audit menjelaskan kompetensi sebagai ukuran mutu yang berkaitan pendidikan, pengetahuan, keahlian, keterampilan, dan pengalaman yang dimiliki oleh auditor. Menurut Kamus Kompetensi LOMA, 1998 (dalam Alim et al., 2007) mendifinisikan 
kompetensi sebagai aspek-aspek pribadi dari seorang pekerja yang memungkinkan dia untuk mencapai kinerja superior. Lebih lanjut oleh Alim, M.N, et al. (2007) menjelaskan aspek-aspek pribadi ini mencakup sifat, motif-motif, sistem nilai, sikap, pengetahuan dan keterampilan dimana kompetensi akan mengarahkan tingkah laku, sedangkan tingkah laku akan menghasilkan kinerja.

Profesi auditor intern pemerintahan relatif berbeda dengan profesi auditor intern yang bekerja pada sektor swasta. Untuk dapat menerima penugasan pemeriksaan seorang PNS harus memiliki Jabatan Fungsional Auditor (JFA) yang persyaratannya diatur oleh Peraturan Menteri Pendayagunaan Aparatur Negara No. Per/220/ M.PAN/7 / 2008 tentang Jabatan Fungsional Auditor dan Angka Kreditnya. Dalam permenpan tersebut dijelaskan, untuk dapat menduduki Jabatan Fungsional Auditor pada setiap jenjangnya, seorang PNS harus memiliki kecukupan angka kredit, di mana angka kredit tersebut ditentukan dengan mempertimbangkan dua unsur, yaitu: unsur utama dan unsur penenunjang. Unsur utama meliputi: pendidikan, pengawasan, dan pengembangan profesi, sedangkan unsur penunjang terdiri atas: pengalaman dan aktualisasi pengetahuan dalam kegiatan seminar-seminar maupun pelatihan-pelatihan. Melalui mekanisme tersebut diharapkan auditor memiliki tujuh kompetensi minimimal yang disyaratkan standar audit. Ketujuh kompetensi tersebut, antara lain: kompetensi bidang manajemen risiko, pengendalian Intern, dan tata kelola sektor publik; kompetensi bidang strategi kegiatan audit intern; kompetensi bidang pelaporan hasil audit intern; kompetensi bidang sikap profesional; kompetensi bidang komunikasi; kompetensi bidang lingkungan pemerintahan; dan kompetensi bidang manajemen pengawasan.

Berbeda dengan standar kompetensi menurut permenpan, Sukriah et al. (2009) berpendapat kompetensi auditor internal tidak saja diukur atas pendidikan atau pengetahuan, serta keahlian khusus yang diperoleh dari pengembangan profesi, tetapi juga kompetensi harus mencerminkan mutu personal seorang auditor.

Penelitian pengaruh kompetensi terhadap kinerja telah banyak dilakukan, bukan saja pada profesi auditor internal tetapi profesi auditor yang bekerja pada KAP. Penelitian yang dilakukan oleh Permatasari et al. (2016) menemukan bahwa kompetensi auditor inspektorat Provinsi Bali, Kabupaten Bangli, dan Kabupaten Klungkung dapat meningkatkan kinerja auditor. Temuan yang sama juga dihasilkan dari penelitian Soedarsa et al. (2012) yang menemukan bahwa kompetensi auditor Inspektorat Provinsi Lampung dapat meningkatkan kinerja auditor.

\section{Perilaku Politik Pimpinan}

Kajian perilaku politik pimpinan dalam organisasi profesional merupakan suatu kajian dengan paradigma yang masih relatif baru (Boddewyn dan Brewer, 1994). Perilaku pimpinan menjadi menarik untuk dikaji, mengingat peranan strategis yang dimiliki oleh pimpinan dalam organisasi. Berkaitan dengan organisasi inspektorat, standar audit sesi 3000 menyebutkan peranan strategis Pimpinan APIP yang berkaitan dengan pengelola kegiatan audit intern, yang terdiri atas: menyusun rencana kegiatan audit, mengkomunikasikan dan meminta persetujuan rencana kegiatan audit tahunan, mengelola sumber daya, menetapkan kebijakan dan prosedur, melakukan koordinasi, menyampaikan laporan berkala, dan menindaklanjuti pengaduan masyarakat ( $d u$ mas). Sehubungan dengan peranan strategis pimpinan tersebut, Ahearn et al. (2004) menekankan peranan para pemimpin dalam "membangun tim" dimana para pemimpin tersebut mengarahkan tim ke arah misi dan visi organisasi.

Untuk menjamin efektivitas pelaksanaan peranan strategis, Pimpinan APIP dilengkapi dengan kekuasaan, kekuasaan inilah yang cenderung disalahgunakan sehingga memunculkan perilaku politik pimpinan (leaderships political behavior). 
Greenberg, dan Baron, 1997 (dalam Jafarani et al., 2012) mendefenisikan perilaku politik sebagai tindakan ilegal atau menyimpang yang dilakukan oleh pimpinan dengan mempengaruhi orang lain atau anggota organisasi untuk mencapai tujuan pribadi tertentu. Lebih lanjut Curtis, 2003 (dalam Jafarani et al., 2012) menekankan bahwa aspek perilaku politik pimpinan selalu dijumpai pada organisasi dan menjadi permasalahan yang tidak dapat dihindarkan. Pendapat Curtis itu, diperkuat dengan hasil penelitian Buchanan (2008) yang menemukan bahwa perilaku politik merupakan hal umum yang telah dipraktekan oleh 250 manager perusahan di Inggris.

Berkaitan dengan aspek perilaku politik dalam organisasi, Kondalkar (2007) mengemukakan lima faktor penyebab, seperti: persaingan untuk mendapatkan sumber daya, pembuatan keputusan yang tidak terprogram, ketidakjelasan tujuan, perubahan struktur organisasi, dan pengaruh dari luar organisasi. Dari lima faktor penyebab tersebut, maka yang paling relevan untuk menjelaskan perilaku politik pimpinan pada organisasi inspektorat adalah ketidakjelasan tujuan. Seperti diketahui bahwa peranan dan fungsi inspektorat kabupaten atau kota memiliki fungsi yang dilematis, dimana satu sisi inspektorat harus melaksanakan pemeriksaan yang objektif terhadap entitas pemerintahan daerah yang diperiksanya, sementara di sisi lain inspektorat juga merupakan bagian dari pemerintahan daerah itu sendiri. Hal ini menyebabkan perilaku politik pimpinan sebagai penanggung jawab lebih cenderung "menjaga nama baik" entitas yang diperiksanya ketimbang memberikan penilaian yang objektif. Motiv untuk "menjaga nama baik" tersebut mendorong perilaku politik pimpinan. Menurut Sukriah et al. (2009) yang meneliti 154 auditor pada enam Inspektorat Provinsi dan Kabupaten atau Kota di Pulau Lombok, menemukan pada saat penyusunan perencanaan pemeriksaan maupun pelaksanaan pemeriksaan oleh auditor, masih ada intervensi pimpinan untuk menentukan, mengeliminasi atau memodifikasi bagian-bagian tertentu yang akan diperiksa serta intervensi atas prosedur-prosedur yang dipilih oleh auditor.

Sedikit berbeda dengan pendapat Sukriah et al. (2009) yang mengemukakan bahwa perilaku politik pimpinan dalam bentuk intervensi dapat dilakukan pada saat perencanaan maupun pada saat pemeriksaan, Willauer (2005) menekankan aspek perilaku politik pimpinan justru terjadi pada saat penyusunan perencanaan atau penyusunan program. Lebih lanjut Willauer (2005) mengembangkan empat indikasi telah terjadinya perilaku politik pimpinan dalam perencanaan, yang terdiri atas: efektivitas implementasi prinsip objektivitas dalam perencanaan, dasar pembuatan perencanan, kepentingan yang mendominasi dalam proses perencanaan, dan hasil dari proses perencanaan.

Penelitian perilaku politik dengan kaitannya dengan kinerja di kalangan karyawan dan manager telah banyak dilakukan di luar negeri. Penelitian yang dilakukan oleh Randall, et al. (1999) terhadap 128 karyawan perusahaan manufaktur pada tiga kota di Amerika Serikat menemukan bahwa perilaku politik memiliki pengaruh negatif yang signifikan terhadap kinerja, walaupun tingkat hubungan keduanya masih lemah. Selain itu, Randall et al. (1999) juga menemukan perilaku politik memiliki pengaruh positif yang signifikan terhadap organizational citizenship behaviors individual, walapun memiliki tingkat hubungan keduanya juga masih lemah. Organizational citizenships behaviors individual adalah kesediaan individu organisasi untuk melakukan discretionary (hal yang tidak biasa), dan apa yang dilakukannya tidak memiliki imbalan kompensasi langsung, namun tindakannya itu dianggap berguna bagi organisasi (Moorman dan Blakely, 1995).

Bodla et al., (2014) meneliti 1.163 karyawan yang sedang menempuh program magister manajemen bisnis di Pakistan, menemukan bahwa pertukaran sosial (social exchange) memediasi sempurna hubungan antara perilaku politik dengan kinerja karya- 
wan. Social exchange theory yang merupakan suatu konsep untuk memahami perilaku anggota organisasi di tempat kerja (Cropanzano dan Mitchell, 2005). Menurut social exchange theory, untuk menghilangkan dampak buruk perilaku politik, organisasi harus memenuhi kebutuhan yang menjadi tuntutan pekerja yang berperilaku politik tersebut.

\section{Pengembangan Hipotesis Model Mediasi}

Dengan mengacu pada teori political behavior, dan temuan hasil penelitian Bodla et al. (2014) yang menemukan hubungan antara perilaku politik dengan kinerja merupakan hubungan tidak langsung, serta dengan mempertimbangkan peranan pimpinan yang dapat mempengaruhi kompetensi anggota tim seperti yang dikemukakan oleh Ahearn et al. (2004), maka dapat diajukan model mediasi seperti ditunjukkan dengan Gambar 1.

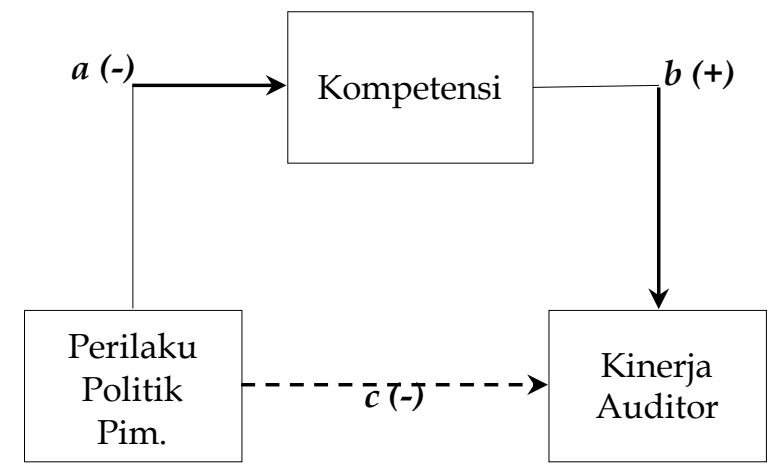

\section{Gambar 1 \\ Rerangka Konseptual Model Mediasi}

Gambar 1 menunjukkan hubungan antara perilaku politik pimpinan terhadap kinerja auditor merupakan hubungan tidak langsung (indirect effect) melalui kompetensi auditor sebagai pemediasi (mediating or intervening variable). Model ini sesuai dengan proposisi teori perilaku politik yang menyatakan perilaku politik pimpinan berpengaruh negatif terhadap kompetensi auditor pada saat melaksanakan pemeriksaan (jalur a) dan kompetensi auditor pada saat melakukan pemeriksaan berpengaruh positif terhadap kinerja auditor (jalur b). Argumentasi yang menjelaskan tentang pengaruh negatif perilaku politik pimpinan terhadap kompetensi auditor (jalur a) dalam Gambar 1 berdasarkan teori perilaku politik adalah sebagai berikut:

Peran pimpinan dalam organisasi inspektorat adalah mengelola kegiatan pemeriksaan agar pemeriksaan sesuai dengan perencanaan dan mencapai tujuan-tujuan yang telah ditetapkan. Ahearn et al. (2004) mengemukakan bahwa pimpinan dapat mengarahkan tim yang menjadi anggotanya. Sementara itu, berkaitan dengan organisasi pimpinan inspektorat Sukriah et al. (2009) menemukan sehubungan dengan ketidakjelasan tujuan inspektorat dalam memeriksa sesama rekan dalam pemerintahan daerah, sering menimbulkan intervensi dari pimpinan. Intervensi inilah yang menyebabkan penggunaan kompetensi yang dimiliki oleh auditor menjadi tidak maksimal.

Argumentasi tentang pengaruh positif kompetensi auditor terhadap kinerja auditor (jalur b) dalam Gambar 1 berdasarkan standar audit adalah sebagai berikut:

Standar audit mensyaratkan beberapa kompetensi yang harus dimiliki auditor dalam melaksanakan pemeriksaan. Kompetensi yang dimiliki auditor dibutuhkan agar pemeriksaan sesuai dengan rencana dan mencapai tujuan-tujuan yang telah ditetapkan, sehingga auditor mampu menyelesaikan tugas dan tanggung jawab yang dibebankan kepadanya. Kemampuan auditor dalam menyelesaikan tugas dan tanggung jawab secara tepat waktu dan sesuai standar capaian yang telah ditetapkan inilah yang menjadi ukuran kinerja auditor.

Berdasarkan kedua argumentasi di atas, serta untuk mengisi theory gap dan research gap seperti yang telah diuraikan pada bagian awal, maka dapat diajukan hipotesis bahwa pengaruh perilaku politik pimpinan adalah tidak langsung (indirect effect) terhadap kinerja auditor dengan kompetensi auditor sebagai variabel pemediasi. Penelitian ini tidak mengajukan hipotesis tentang pengaruh langsung (direct effect) perilaku politik pimpinan terhadap kinerja auditor sehingga jalur c pada Gambar 1 digambar- 
kan sebagai garis putus-putus. Perilaku politik pimpinan bukanlah faktor yang dapat menaikan kinerja auditor, karena pada prakteknya kegiatan pemeriksaan entitas organisasi pemerintah daerah dilakukan oleh auditor. Hal itu dikarenakan tugas pimpinan dalam organisasi hanyalah mengarahkan anggota tim (Ahearn et al., 2004). Model mediasi ini didukung penelitian Bodla et al. (2014) yang menemukan hubungan antara perilaku politik merupakan hubungan tidak langsung. Sehingga hipotesis yang diajukan pada model ini yaitu:

$\mathrm{H}_{1}$ : Perilaku politik pimpinan berpengaruh negatif tidak langsung terhadap kinerja auditor melalui kompetensi auditor.

\section{Pengembangan Hipotesis Model Moderasi}

Selain model mediasi, terdapat kemungkinan model moderasi dalam hubungan antara perilaku politik pimpinan, kompetensi auditor, dan kinerja auditor. Randall et al. (1999) berargumen walaupun perilaku politik berpengaruh signifikan negatif terhadap kinerja, tetapi hubungan (kolerasi) keduanya masih lemah. Merujuk pada temuan tersebut, maka dimungkinkan perilaku politik pimpinan merupakan variabel pemoderasi dalam hubungan antara kompetensi auditor dengan kinerja auditor, seperti tampak pada Gambar 2.

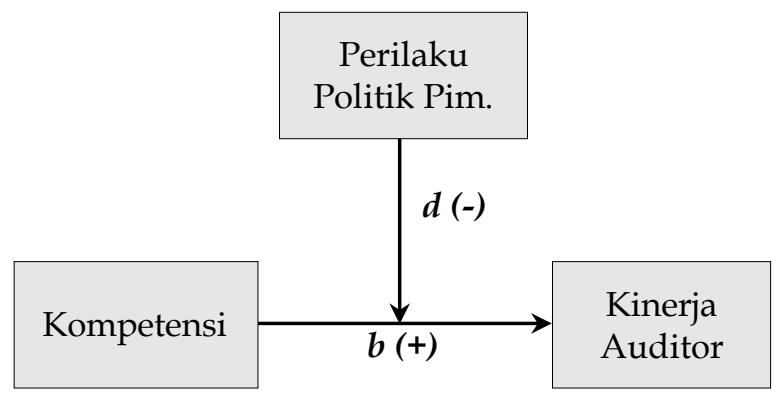

\section{Gambar 2}

\section{Rerangka Konseptual Model Moderasi}

Pada Gambar 2 menunjukkan bahwa pengaruh positif kompetensi auditor terhadap kinerja auditor diperlemah dengan perilaku politik pimpinan (jalur d). Dalam hal ini perilaku politik pemimpin bertindak sebagai pemoderasi yang memperlemah. Model pada Gambar 2, berimplikasi adanya interaksi negatif antara perilaku politik pemimpin dengan kompetensi auditor dalam mempengaruhi kinerja auditor. Semakin intensif perilaku politik pemimpin, maka semakin kecil pengaruh kompetensi terhadap kinerja.

Ahearn et al. (2004) menyatakan tugas seorang pimpinan adalah membangun dan mengarahkan anggota tim untuk mencapai tujuan organisasi. Hal ini sesuai dengan pendekatan kontinjensi, yang berarti efektivitas kompetensi auditor dalam pemeriksaan bergantung pada arahan dan koordinasi yang diberikan oleh pimpinan.

Berdasarkan argumentasi di atas, serta untuk mengisi theory gap dan research gap seperti yang telah diuraikan pada bagian awal, maka dapat diajukan hipotesis bahwa pengaruh kompetensi auditor terhadap kinerja auditor dimoderasi oleh perilaku politik pimpinan. Dalam situasi tertentu pengaruh positif kompetensi terhadap kinerja auditor dapat menurun bahkan hilang karena motivasi pemimpin untuk berperilaku politik semakin besar. Sehingga hipotesis yang diajukan pada model ini, yaitu:

$\mathrm{H}_{2}$ : Interaksi kompetensi auditor dan perilaku politik pimpinan berpengaruh negatif terhadap kinerja auditor.

\section{METODE PENELITIAN Pendekatan Penelitian}

Penelitian ini mengajukan dua model penelitian, yaitu: model mediasi dan model moderasi. Model mediasi dikembangkan dari penelitian Bodla et al. (2014), yang menyatakan hubungan antara perilaku politik dengan kinerja merupakan hubungan tidak langsung. Bedanya dengan penelitian ini, Bodla et al. (2014) menggunakan social exchange (pertukaran sosial) untuk membuktikan pengaruh tidak langsung positif antara perilaku politik dengan kinerja, sedangkan pada penelitian ini menggunakan kompetensi untuk membuktikan pengaruh tidak langsung negatif antara peri- 
laku politik dengan kinerja. Model moderasi dikembangkan dari penelitian Randall et al. (1999), yang menyatakan meskipun perilaku politik berpengaruh signifikan negatif terhadap kinerja, tetapi hubungan (kolerasi) diantara keduanya masih sangat lemah, sehingga dapat diindikasikan hubungan antara perilaku politik, kompetensi, dan kinerja merupakan model moderasi. Ferdinand (2014), menjelaskan model moderasi sebagai sebuah model bersyarat atau "conditional model" sebagai suatu model dimana satu variabel atau beberapa variabel independen mempengaruhi satu variabel dependen, dengan syarat bahwa pengaruhnya akan menjadi lebih kuat atau menjadi lebih lemah. Berdasarkan argumen Randall et al. (1999), maka penelitian ini menggunakannya sebagai variabel moderasi yang memperlemah pengaruh kompetensi dengan kinerja.

Ditinjau dari tujuannya, desain riset ini dapat digolongkan sebagai desain riset kausalitas atau sering disebut juga sebagai explanatory research. Desain riset kausalitas merupakan desain riset yang digunakan dengan tujuan menguji pengaruh, hubungan, atau dampak variabel independen terhadap variabel dependen atau konstruk eksogen terhadap konstruk endogen (Chandrarin, 2017).

\section{Populasi dan Sampel}

Penelitian ini dilakukan di seluruh Inspektorat Kabupaten atau Kota yang ada di Jawa Barat, yang terdiri atas 18 kabupaten dan 9 kota. Hal ini dikarenakan populasi penelitian yang menjadi subyek penelitian adalah seluruh auditor internal yang bekerja di inspektorat kabupaten atau kota yang berada di Jawa Barat. Pengambilan sampel menggunakan teknik proportionate stratified random sampling. Teknik pengambilan sampel proportionate stratified random sampling digunakan jika populasi mempunyai anggota atau unsur yang tidak homogen dan berstrata secara proporsional (Ghozali, 2016; Sugiyono, 2014). Teknik pengambilan sam- pel menggunakan teknik ini terdiri atas tiga langkah, yaitu: pertama, menentukan ukuran sampel. Pada penelitian ini ukuran sampel ditentukan dengan menggunakan rumus Isaac dan Michael, 1981 (dalam Sugiyono, 2014) seperti terlihat pada persamaan 1; kedua, menentukan besaran rasio masingmasing inspektorat; dan ketiga, menentukan ukuran sampel masing-masing inspektorat berdasarkan rasio yang didapat.

$S=\frac{\lambda^{2} \cdot N \cdot P \cdot Q}{d^{2}(N-1)+\lambda^{2}} \ldots \ldots \ldots \ldots \ldots \ldots .$. persamaan 1

Keterangan: $S$ (jumlah sampel); $\lambda^{2}$ (chi kuadrad, untuk derajat kebebasan 1 dengan kesalahan 5\% maka chi kuadrad 3.841); N (jumlah populasi); P (peluang benar 5\%); Q (peluang salah 5\%); dan d (perbedaan antara sampel yang diharapkan dan yang terjadi $5 \%)$.

Berdasarkan data Pusbin BPKP Republik Indonesia sebagai instansi yang melakukan pembinaan tehadap profesi auditor internal pemerintahan, sampai pada akhir tahun 2018 jumlah auditor pada 27 Inspektorat Kabupaten atau Kota di Jawa Barat berjumlah 461 yang terdiri atas: 54 auditor terampil dan 407 auditor ahli. Berdasarkan jumlah populasi tersebut, dengan menggunakan persamaan 1 dapat ditentukan ukuran sampel sebagai berikut:

$S=\frac{3.841 \times 461 \times 0.5 \times 0.5}{0.05^{2}(461-1)+3.841 \times 0.5 \times 0.5} \quad 209,8$ dibulatkan 210

Hasil penentuan rasio, proporsi ukuran sampel, dan jumlah sampel yang digunakan pada penelitian in, ditunjukkan dengan Tabel 1.

\section{Teknik dan Prosedur Pengumpulan Data}

Chandrarin (2017) menjelaskan dalam penelitian yang menggunakan data primer, yaitu data yang berasal langsung dari obyek penelitian atau responden data dapat dikumpulkan dengan instrumen kuesioner atau materi wawancara. 
Tabel 1

Populasi dan Sampel

\begin{tabular}{|c|c|c|c|c|c|c|c|}
\hline \multirow{3}{*}{ No. } & \multirow{3}{*}{ Kode } & \multirow{3}{*}{ Inspektorat } & \multicolumn{5}{|c|}{ Proportionate Stratified Random Sampling } \\
\hline & & & \multicolumn{3}{|c|}{ Populasi } & \multicolumn{2}{|c|}{ Sampel } \\
\hline & & & $A T$ & $A A$ & Total & Rasio & Jumlah \\
\hline 1 & 32.01 & Kab. Bogor & 6 & 33 & 39 & $8.5 \%$ & 18 \\
\hline 2 & 32.02 & Kab. Sukabumi & 0 & 11 & 11 & $2.4 \%$ & 5 \\
\hline 3 & 32.03 & Kab. Cianjur & 3 & 7 & 10 & $2.2 \%$ & 5 \\
\hline 4 & 32.04 & Kab. Bandung & 2 & 7 & 9 & $2.0 \%$ & 4 \\
\hline 5 & 32.05 & Kab. Garut & 0 & 29 & 29 & $6.3 \%$ & 13 \\
\hline 6 & 32.06 & Kab. Tasikmalaya & 3 & 12 & 15 & $3.3 \%$ & 7 \\
\hline 7 & 32.07 & Kab. Ciamis & 2 & 11 & 13 & $2.8 \%$ & 6 \\
\hline 8 & 32.08 & Kab. Kuningan & 3 & 10 & 13 & $2.8 \%$ & 6 \\
\hline 9 & 32.09 & Kab. Cirebon & 4 & 34 & 38 & $8.2 \%$ & 17 \\
\hline 10 & 32.10 & Kab. Majalengka & 0 & 7 & 7 & $1.5 \%$ & 3 \\
\hline 11 & 32.11 & Kab. Sumedang & 1 & 20 & 21 & $4.6 \%$ & 10 \\
\hline 12 & 32.12 & Kab. Indramayu & 0 & 14 & 14 & $3.0 \%$ & 6 \\
\hline 13 & 32.13 & Kab. Subang & 3 & 4 & 7 & $1.5 \%$ & 3 \\
\hline 14 & 32.14 & Kab. Purwakarta & 3 & 13 & 16 & $3.5 \%$ & 7 \\
\hline 15 & 32.15 & Kab. Karawang & 2 & 13 & 15 & $3.3 \%$ & 7 \\
\hline 16 & 32.16 & Kab. Bekasi & 2 & 22 & 24 & $5.2 \%$ & 11 \\
\hline 17 & 32.17 & Kab. Bandung Barat & 1 & 12 & 13 & $2.8 \%$ & 6 \\
\hline 18 & 32.18 & Kab. Pangandaran & 0 & 5 & 5 & $1.1 \%$ & 2 \\
\hline 19 & 32.71 & Kota Bogor & 1 & 19 & 20 & $4.3 \%$ & 9 \\
\hline 20 & 32.72 & Kota Sukabumi & 0 & 20 & 20 & $4.3 \%$ & 9 \\
\hline 21 & 32.73 & Kota Bandung & 5 & 14 & 19 & $4.1 \%$ & 9 \\
\hline 22 & 32.74 & Kota Cirebon & 0 & 5 & 5 & $1.5 \%$ & 3 \\
\hline 23 & 32.75 & Kota Bekasi & 4 & 35 & 39 & $8.5 \%$ & 18 \\
\hline 24 & 32.76 & Kota Depok & 0 & 12 & 12 & $2.6 \%$ & 5 \\
\hline 25 & 32.77 & Kota Cimahi & 0 & 12 & 12 & $2.6 \%$ & 5 \\
\hline 26 & 32.78 & Kota Tasikmalaya & 8 & 14 & 22 & $4.8 \%$ & 10 \\
\hline \multirow[t]{2}{*}{27} & 32.79 & Kota Banjar & 1 & 12 & 13 & $2.8 \%$ & 6 \\
\hline & & Jumlah: & 54 & 407 & 461 & 100 & 210 \\
\hline
\end{tabular}

Ket.: AT (Auditor Terampilan); AA (Auditor Ahli)

Sumber: Pusbin BPKP-RI (2018)

Oleh karena itu, teknik dan prosedur pengumpulan data dalam penelitian ini sebagai berikut: a) Kuesioner, kuesioer merupakan instrumen yang berisi daftar pertanyaan serta merefleksikan indikator dari variabel yang akan diukur. Pada penelitian ini, daftar pertanyaan peneliti tersebut disampaikan kepada responden dalam bentuk instrumen kuesioner tercetak (hard copy). Setelah kuesioner disampaikan kepada responden, untuk diisi dan kemudian dikembalikan. Langkah selanjutnya adalah melakukan evaluasi kuesioner yang kembali untuk menentukan apakah kuesioner tersebut terisi sempurna sehingga layak untuk digunakan sebagai data penelitian. Data dari jawaban responden tersebut yang pada dasarnya merupakan data kualitatif kemudian dikuantifisir, yaitu data penelitian kualitatif yang diangkakan (di-skoring). b) Wawancara, wawancara merupakan teknik pengumpulan data dalam metode survei dengan menggunakan pertanyaan secara lisan kepada subyek penelitian, baik dengan 
tujuan untuk mengumpulkan data penelitian maupun melengkapi hal-hal yang diperlukan dalam penelitian. Pada penelitian ini dilakukan wawancara yang bertujuan untuk melengkapi hal-hal yang diperlukan dalam penelitian, yaitu: wawancara yang dilakukan di Inspektorat Kabupaten Sukabumi dan Pusat Pembinaan BPKP RI. Wawancara di Inspektorat Kabupaten Sukabumi dilakukan dalam rangka pengembangan instrumen kuesioner penelitian.

Hal itu dilakukan untuk mengetahui apakah kuesioner yang akan digunakan memiliki relevansi dengan obyek penelitian baik dari segi konteks maupun konten. Sedangkan, wawancara yang dilakukan di Pusat Pembinaan Badan Pengawas Keuangan BPKRI RI dilakukan dalam rangka menggali informasi jumlah auditor yang telah memiliki Jabatan Fungsional Auditor (JFA) di 27 inspektorat Kabupaten atau Kota di Jawa Barat.

\section{Variabel dan Definisi Operasional Kalasifikasi Variabel Penelitian}

Ghozali (2016) menyatakan bahwa variabel adalah konstruk atau konsep yang dapat diukur atau dilekatkan suatu nilai numerik. Oleh karena itu, berdasarkan cara pengukurannya (outer) variabel dapat dibedakan atas dua, yaitu: apakah variabel dapat diukur secara langsung ataukah variabel harus prediksi melalui indikator-indikatornya. Variabel yang diprediksi dengan indikator dikenal sebagai konstruk atau variabel laten atau unobserved variable, sedangkan indikator yang memprediksi dikenal dengan variabel manifest atau unobserved variable. Selain jenis-jenis variabel seperti yang telah diuraikan di atas, variabel juga dapat dibedakan berdasarkan hubungannya sesama variabel (inner), yang dapat dibedakan atas empat, yaitu: variabel independen, variabel dependen, variabel pemediasi atau variabel antara atau variabel intervening, variabel moderasi, dan variabel kontrol. a) variabel independen, merupakan variabel yang mempengaruhi variabel lain, b) variabel dependen, merupakan variabel yang dipe- ngaruhi variabel lain, c) variabel pemediasi atau variabel antara atau variabel intervening, merupakan variabel yang berada di antara variabel independen dan dependen. Variabel pemediasi digunakan untuk menggambarkan adanya hubungan tidak langsung (indirect effect) antara variabel independen dengan variabel dependen, $d$ ) variabel pemoderasi, merupakan variabel yang yang memperkuat atau memperlemah hubungan atau pengaruh variabel independen terhadap variabel dependen, dan e) variabel kontrol, merupakan variabel tambahan yang dimasukan dalam model yang bertujuan untuk menekan kesalahan-kesalahan yang ada dan mungkin timbul dalam proses riset. Penelitian ini menggunakan empat jenis variabel dari lima jenis variabel seperti yang telah diuraikan di atas, yaitu: pada model pertama (model mediasi) perilaku politik pimpinan sebagai variabel independen, kompetensi auditor sebagai variabel pemediasi, dan kinerja auditor sebagai variabel independen. Sementara itu, pada model kedua (model moderasi) kompetensi auditor sebagai variabel independen, perilaku politik pimpinan sebagai variabel pemoderasi, dan kinerja auditor sebagai variabel independen.

\section{Definisi Operasional Variabel Penelitian}

Berdasarkan klasfikasi variabel yang akan digunakan seperti yang telah diuraikan, maka definisi operasional variabel dalam penelitian ini, yaitu:

\section{Kinerja Auditor}

Kinerja (performance) merupakan suatu ukuran yang dapat digunakan untuk menetapkan perbandingan hasil pelaksanaan tugas, tanggung jawab yang diberikan oleh organisasi pada periode tertentu dan relatif dapat digunakan untuk mengukur prestasi kerja atau kinerja organisasi (Gibson et al. 1996). Variabel ini diukur empat indikator, tiga indikator dikembangkan aspek pengukuran kinerja menurut Libby, 1995 (dalam Marganingsih dan Martani, 2010) yaitu: "pengalaman", "pengetahuan", dan "kemampuan". Dan satu indikator menurut 
Marganingsih dan Martani (2010), yaitu: "ketaatan kode etik". Variabel "kinerja auditor" diukur dengan enam item instrumen, indikator "pengalaman" diukur dengan satu item instrumen (1Pa1), indikator "pengetahuan" diukur dengan dua item instrumen (2Pa2, dan 3Pa3), indikator "kemampuan" diukur dengan dua item instrumen $(4 \mathrm{Km} 1$, dan $5 \mathrm{Km} 2)$, serta indikator "ketaatan kode etik" diukur dengan satu item instrumen (6KE1). Respon responden diukur dengan skala "likert" 1-5.

\section{Perilaku Politik Pimpinan}

Perilaku politik pimpinan merupakan tindakan ilegal atau menyimpang yang dilakukan oleh pimpinan dengan mempengaruhi orang lain atau anggota organisasi untuk mencapai tujuan pribadi tertentu (Greenberg, dan Baron, 1997 dalam Jafarani et al., 2012). Variabel ini diukur dengan empat indikator pengukuran perilaku politik menurut Willauer (2005), yaitu: "objektivitas", "dasar perencanaan", "proses perencanaan", dan "hasil perencanaan". Variabel "perilaku politik pimpinan" diukur dengan empat item instrumen, dan masing-masing indikator diukur dengan satu item instrumen (7OP1, 8DP1, 9PP1, dan 10HP1). Respon responden diukur dengan skala "likert" 1-5.

\section{Kompetensi auditor}

Kompetensi merupakan kemampuan profesional yang diperlukan auditor untuk melaksanakan tugas dan tanggung jawabnya (Standar Audit Intern Pemerintah, 2014). Variabel ini diukur dengan tiga indikator pengukuran kompetensi auditor inspektorat menurut Sukriah et al., (2009), yaitu: "mutu personal", "pengetahuan umum", dan "keahlian khusus". Variabel "kompetensi auditor" diukur dengan sembilan item instrumen, yaitu: indikator "mutu personal" diukur dengan tiga item instrumen (1MP1, 2MP2, dan 3MP3), indikator "pengetahuan umum" diukur dengan empat item instrumen (4PU1, 5PU3, 6PU3, dan 7PU4), serta indikator "keahlian khusus" diukur dengan dua item instrumen (8KK1, dan 9KK2).
Respon responden diukur dengan skala "likert" 1-5.

\section{Teknik Analisis Data}

Teknik analisis data yang digunakan dalam penelitian ini Component Based Structural Equation Modeling (CBSEM) dengan bantuan software SmartPLS Version 3.0. Analisis data menggunakan pendekatan CBSEM bertujuan untuk melakukan konfirmasi terhadap teori, yang sekaligus dapat digunakan untuk menjelaskan ada atau tidaknya hubungan antar variabel laten atau konstruk (Ghozali, 2014). Oleh karena itu, teknik analisis data dengan menggunakan CBSEM terdiri dua pengujian atau analisis, yaitu: outer model yang menguji dan menganalisa hubungan antara observed variable (indikator atau item pertanyaan) dengan konstruknya (unobserved variable) dan inner model yang menguji dan menganalisa hubungan antara satu konstruk dengan konstruk lainnya.

\section{Analisis Outer Model}

Analisis outer model, dilakukan dengan melakukan serangkaian evaluasi antara observed variable dalam bentuk indikator atau item pertanyaan dengan konstruk yang dibentuknya (unobserved variable). Evaluasi ini terdiri atas: evaluasi validitas (convergent validity dan discriminat validity), evaluasi reliabilitas (composite realibility dan cronbach's alpha), serta evaluasi estimasi koefisien observed variable dengan konstruknya (unobserved variable).

\section{Analisis Inner Model}

Analisis inner model, dilakukan dengan melakukan serangkaian evaluasi antara satu unobserved atau konstruk yang satu dengan konstruk yang lainya yang dibentuk dalam model penelitian. Evaluasi ini terdiri atas: evaluasi kontribusi $\left(\mathrm{R}^{2}\right)$, evaluasi substantif $\left(\mathrm{f}^{2}\right)$, evaluasi prediksi relevansi $\left(\mathrm{Q}^{2}\right)$, dan evaluasi estimasi koefisien sesama unobserved variable yang dibentuk berdasarkan model. Evaluasi terhadap estimasi koefisien inner model selanjutnya digunakan untuk pengujian hipotesis-hipotesis penelitian diajukan. 


\section{ANALISIS DAN PEMBAHASAN \\ Gambaran Data dan Subyek Penelitian}

Penelitian ini menggunakan subyek penelitian auditor pada 27 obyek inspektorat Kabupaten atau Kota yang ada di Jawa Barat, yang terdiri atas: 18 inspektorat Pemerintahan Daerah Kabupaten dan 9 Pemerinta han Daerah Inspektorat Kota. Teknik pengumpulan data dengan cara menyampai- kan kuesioner kepada auditor yang dijadikan responden. Berdasarkan Tabel 2, berkaitan dengan hasil pengumpulan data, dari 210 responden yang diberikan kuesioner, seluruh kuesioner kembali dan setelah dilakukan evaluasi, seluruhnya terisi sempurna sehingga layak untuk diolah lebih lanjut. Sehingga dapat disimpulkan response rate dalam penelitian ini mencapai $100 \%$.

Tabel 2

Hasil Pengumpulan Data

\begin{tabular}{lcc}
\hline \hline \multicolumn{1}{c}{ Keterangan } & Jumlah & Prosentase (\%) \\
\hline Kuesioner disampaikan & 210 & 100 \\
Kuesioner tidak kembali & 0 & 0 \\
Kuesioner kembali & 210 & 100 \\
Kuesioner tidak terisi sempurna & 0 & 0 \\
Kuesioner terisi sempurna & 210 & 100 \\
\hline
\end{tabular}

Sumber: data diolah (2018)

Berdasarkan Tabel 2, berkaitan dengan data demografi responden, sebagian besar responden berada pada usia produktif yaitu berkisar antara 41-50 tahun sebanyak 89 responden $(42,2 \%)$. Responden pria sebanyak 116 responden $(55,2 \%)$, dan respon den wanitar sebanyak $94(44,8 \%)$. Sebagian besar responden berpendidikan sarjana sebanyak 129 (61,4\%). Responden yang memiliki JFA sebagi auditor terampil sebanyak 27 responden $(12,9 \%)$, dan auditor ahli sebanyak 183 responden (87,1\%). Sebagian besar responden memiliki jabatan sebagai anggota tim dalam pemeriksaan sebanyak 99 responden $(47,1 \%)$. Responden yang telah mengikuti bimtek (bimbingan teknik) sebanyak 187 responden (89\%), dan responden yang belum mengikuti bimtek hanya 23 reposnden $(11 \%)$. Dan sebagian besar responden memiliki pengalaman pemeriksaan lebih dari 12 kali sebanyak 154 responden (73,3\%).

\section{Analisis Data}

\section{Analisis Outer Model}

Analisis outer model terdiri atas: evaluasi validitas, evaluasi reliabilitas, dan evalusi outer loadings, yang akan diuraikan sebagai berikut:

\section{Evaluasi Validitas}

Evaluasi validitas merupakan serangkaian evaluasi derajat ketepatan instrumen untuk mengukur apa yang seharusnya diukur (Ghozali, 2016; Ferdinand, 2014). Evaluasi validitas dibedakan kembali atas: convergent validity dan discriminat validity.

\section{a. Convergent Validity}

Convergent validity, merupakan evaluasi untuk mengetahui apakah item pertanyaan atau indikator yang merupakan observed variable dapat mengukur konstruk yang dibentuk. Evaluasi convergent validity dilakukan dengan melakukan evaluasi terhadap loading factor yang dapat dilihat dari nilai original sample. Menurut Ghozali (2014) suatu item pertanyaan (observed variable) memenuhi evaluasi convergent validity jika memiliki loading factor lebih besar atau sama dengan nilai critical value 0,7 , walaupun demikian menurut Chin (1998) dalam Ghozali (2014) pada riset yang masih tahap pengembangan loadings factors 0,5 masih diijinkan. 
Tabel 3

Data Demografi Responden

\begin{tabular}{|c|c|c|c|}
\hline No. & Keterangan & Jumlah & Prosentase (\%) \\
\hline 1. & $\begin{array}{l}\text { Umur: } \\
\text { a. } 20-30 \text { tahun } \\
\text { b. } 31-40 \text { tahun } \\
\text { c. } 41-50 \text { tahun } \\
\text { d. } 51 \text { - } 60 \text { tahun } \\
\text { e. } \geq 60 \text { tahun }\end{array}$ & $\begin{array}{r}10 \\
63 \\
89 \\
47 \\
1\end{array}$ & $\begin{array}{r}4.8 \\
30.0 \\
42.4 \\
22.4 \\
0.4\end{array}$ \\
\hline & Jumlah: & 210 & 100 \\
\hline 2. & $\begin{array}{l}\text { Jenis Kelamin: } \\
\text { a. Pria } \\
\text { b. Wanita }\end{array}$ & $\begin{array}{r}116 \\
94 \\
210\end{array}$ & $\begin{array}{r}55.2 \\
44.8 \\
100\end{array}$ \\
\hline 3. & $\begin{array}{l}\text { Pendidikan Terakhir: } \\
\text { a. SMU atau Sederajat } \\
\text { b. D3/Sederajat } \\
\text { c. S1 (Sarjana) } \\
\text { d. S2 (Pascasarjana) } \\
\text { e. S3 (Doktoral) Jumlah: }\end{array}$ & $\begin{array}{r}3 \\
5 \\
129 \\
69 \\
4 \\
210\end{array}$ & $\begin{array}{r}1.4 \\
2.4 \\
61.4 \\
32.9 \\
1.9 \\
100\end{array}$ \\
\hline 4. & $\begin{array}{l}\text { JFA: } \\
\text { a. Auditor Terampil } \\
\text { b. Auditor Ahli }\end{array}$ & $\begin{array}{r}27 \\
183 \\
210\end{array}$ & $\begin{array}{r}12.9 \\
87.1 \\
100\end{array}$ \\
\hline 5. & $\begin{array}{l}\text { Jabatan Pemeriksaan: } \\
\text { a. Anggota Tim } \\
\text { b. Ketua Tim } \\
\text { c. Pengendali Teknis } \\
\text { d. Pengendali Mutu }\end{array}$ & $\begin{array}{r}99 \\
64 \\
1 \\
6\end{array}$ & $\begin{array}{r}47.1 \\
30.5 \\
19.5 \\
2.9\end{array}$ \\
\hline & Jumlah: & 210 & 100 \\
\hline 6. & $\begin{array}{l}\text { Bimtek: } \\
\text { a. Sudah bimtek } \\
\text { b. Belum bimtek }\end{array}$ & $\begin{array}{r}187 \\
23\end{array}$ & $\begin{array}{l}89.0 \\
11.0\end{array}$ \\
\hline & Jumlah: & 210 & 100 \\
\hline 7. & $\begin{array}{l}\text { Pengalaman Audit: } \\
\text { a. } 1-3 \mathrm{kali} \\
\text { b. } 4-6 \mathrm{kali} \\
\text { c. } 7-9 \mathrm{kali} \\
\text { d. } 10-12 \mathrm{kali} \\
\text { e. }>12 \mathrm{kali}\end{array}$ & $\begin{array}{r}19 \\
9 \\
15 \\
13 \\
154\end{array}$ & $\begin{array}{r}9.0 \\
4.3 \\
7.2 \\
6.2 \\
73.3\end{array}$ \\
\hline & Jumlah: & 210 & 100 \\
\hline
\end{tabular}


Tabel 4

Evaluasi Convergent Validity

\begin{tabular}{|c|c|c|c|c|c|c|c|c|}
\hline \multirow{2}{*}{ Keterangan } & \multicolumn{4}{|c|}{$\begin{array}{c}\text { Model } \\
\text { Mediasi }\end{array}$} & \multicolumn{4}{|c|}{$\begin{array}{c}\text { Model } \\
\text { Moderasi }\end{array}$} \\
\hline & $\begin{array}{l}\text { Original } \\
\text { Sample }\end{array}$ & $\begin{array}{c}\text { Standard } \\
\text { Deviation }\end{array}$ & $\begin{array}{c}T \\
\text { Statistics }\end{array}$ & $\begin{array}{c}P \\
\text { Values }\end{array}$ & $\begin{array}{l}\text { Original } \\
\text { Sample }\end{array}$ & $\begin{array}{c}\text { Standard } \\
\text { Deviation }\end{array}$ & $\begin{array}{c}T \\
\text { Statistics }\end{array}$ & $\begin{array}{c}P \\
\text { Values }\end{array}$ \\
\hline \multicolumn{9}{|c|}{ Kompetensi Auditor: } \\
\hline 1MP1 & 0.669 & 0.058 & 11.539 & 0.000 & 0.680 & 0.054 & 12.533 & 0.000 \\
\hline 2MP2 & 0.356 & 0.108 & 3.300 & 0.001 & 0.369 & 0.101 & 3.651 & 0.000 \\
\hline 3MP3 & 0.729 & 0.037 & 19.802 & 0.000 & 0.719 & 0.038 & 19.037 & 0.000 \\
\hline 4PU1 & 0.838 & 0.026 & 31.849 & 0.000 & 0.835 & 0.027 & 30.586 & 0.000 \\
\hline 5PU2 & 0.858 & 0.023 & 37.213 & 0.000 & 0.854 & 0.026 & 33.058 & 0.000 \\
\hline 6PU3 & 0.817 & 0.027 & 30.745 & 0.000 & 0.816 & 0.027 & 30.192 & 0.000 \\
\hline 7PU4 & 0.788 & 0.034 & 23.099 & 0.000 & 0.791 & 0.032 & 25.078 & 0.000 \\
\hline 8KK1 & 0.787 & 0.047 & 16.930 & 0.000 & 0.785 & 0.045 & 17.380 & 0.000 \\
\hline 9KK2 & 0.762 & 0.033 & 23.180 & 0.000 & 0.764 & 0.033 & 23.445 & 0.000 \\
\hline $10 \mathrm{KK} 3$ & 0.795 & 0.031 & 25.635 & 0.000 & 0.795 & 0.031 & 25.370 & 0.000 \\
\hline \multicolumn{9}{|c|}{ Perilaku Politik Pimpinan: } \\
\hline 11OP1 & 0.706 & 0.081 & 8.688 & 0.000 & 0.716 & 0.105 & 6.839 & 0.000 \\
\hline 12DP1 & 0.757 & 0.123 & 6.164 & 0.000 & 0.747 & 0.186 & 4.009 & 0.000 \\
\hline 13PP1 & 0.782 & 0.121 & 6.479 & 0.000 & 0.774 & 0.183 & 4.223 & 0.000 \\
\hline $14 \mathrm{HP} 1$ & 0.805 & 0.106 & 7.593 & 0.000 & 0.799 & 0.162 & 4.923 & 0.000 \\
\hline \multicolumn{9}{|c|}{ Kinerja Auditor: } \\
\hline 15Pa1 & 0.815 & 0.029 & 28.567 & 0.000 & 0.815 & 0.029 & 28.469 & 0.000 \\
\hline $16 \mathrm{Pt} 2$ & 0.619 & 0.077 & 7.998 & 0.000 & 0.620 & 0.072 & 8.667 & 0.000 \\
\hline $17 \mathrm{Pt} 3$ & 0.843 & 0.028 & 30.501 & 0.000 & 0.843 & 0.026 & 32.670 & 0.000 \\
\hline 18Km1 & 0.690 & 0.057 & 12.031 & 0.000 & 0.690 & 0.059 & 11.692 & 0.000 \\
\hline $19 \mathrm{Km} 2$ & 0.781 & 0.034 & 23.249 & 0.000 & 0.781 & 0.033 & 23.450 & 0.000 \\
\hline 20KE1 & 0.751 & 0.036 & 21.035 & 0.000 & 0.750 & 0.037 & 20.184 & 0.000 \\
\hline
\end{tabular}

Sumber: data diolah (2018)

Berdasarkan informasi yang disajikan pada Tabel 4, diketahui dari masing-masing item pertanyaan terhadap konstruknya, baik pada model mediasi maupun model moderasi yang diajukan, dari 20 item pertanyaan yang digunakan untuk mengukur kedua model tersebut masih terdapat item pertanyaan yang memiliki loading factor kurang dari 0,7 (0,356 dan 0,369) yaitu item pertanyaan 2MP2 yang mengukur indikator mutu personal, seperti ditunjukan dengan Gambar 1 dan Gambar 2. Dengan demikian, item pertanyaan tersebut harus dikeluarkan dari outer model penelitian.

\section{b. Discriminant validity}

Dicriminant validity, merupakan evaluasi untuk mengetahui apakah suatu konstruk merupakan konsep yang independen atau bebas dengan konstruk lainnya dalam model. Evaluasi discriminant validity dilakukan dengan membandingkan akar Average Variance Extract (AVE) dengan kolerasi diantara konstruk dalam model tersebut. Suatu konstruk memenuhi evaluasi discriminant validity jika akar AVE suatu kontruk tersebut lebih besar dari nilai kolerasinya.

Berdasarkan informasi yang disajikan pada Tabel 5, diketahui semua konstruk yang digunakan dalam masing-masing model, memiliki akar AVE yang lebih besar dari nilai korelasinya, sehingga dapat disimpulkan seluruh konstruk telah memenuhi evaluasi discriminat validity (valid).

\section{Evaluasi Reliabilitas}

Evaluasi reliabilitas berhubungan dengan seberapa jauh pengukuran itu tidak bias (bebas dari kesalahan) sehingga memberikan konsistensi pengukuran sepanjang dan 
berbagai item di dalam instrumen (Ghozali, 2016). Evaluasi reliabilitas dibedakan kembali atas: evaluasi composite reliability dan evaluasi cronbach's alpha.

a) Evaluasi composite reliability

Evaluasi composite reliability bertujuan untuk mengetahui derajat konsistensi inter- nal yang mengukur secara unidimensionalitas konstruk. Evaluasi ini dilakukan dengan menganalisa nilai composite realiability.

Suatu konstruk telah memenuhi evaluasi composite reliability jika nilai composite reliability lebih besar dari ciritical value 0,6.

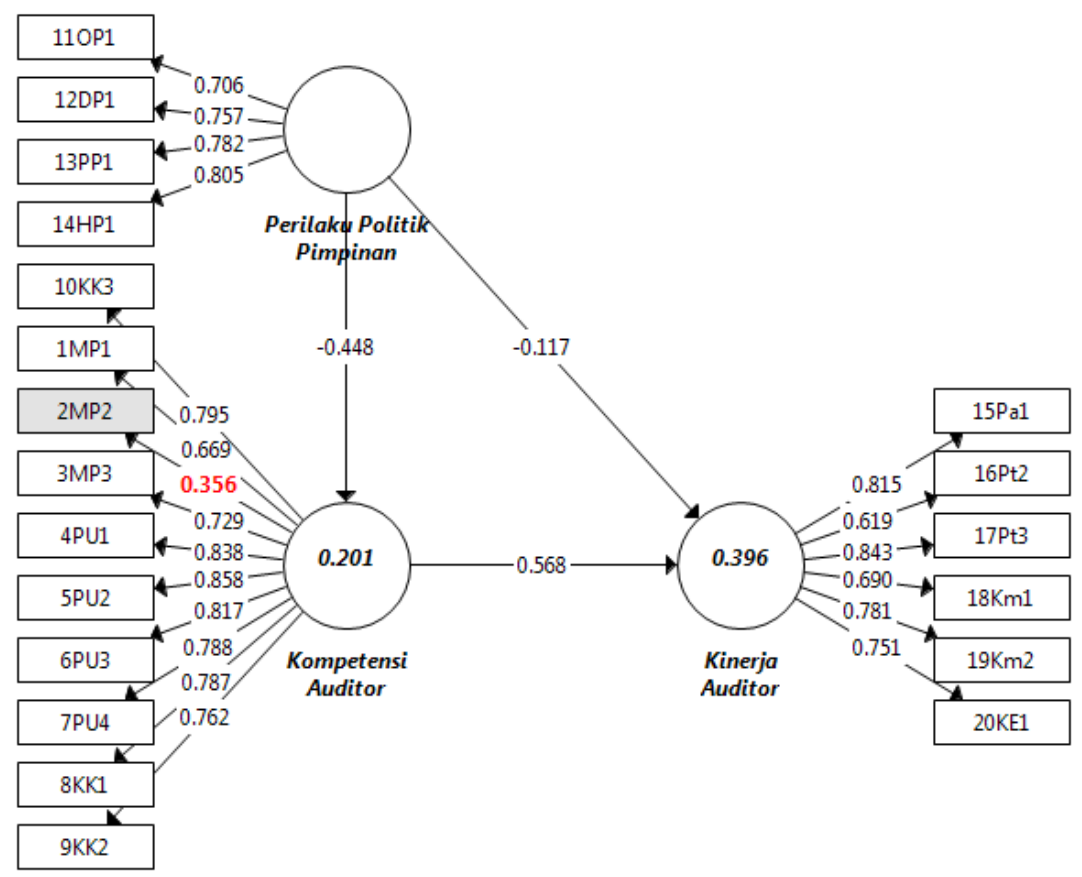

Gambar 3

Model Mediasi Awal
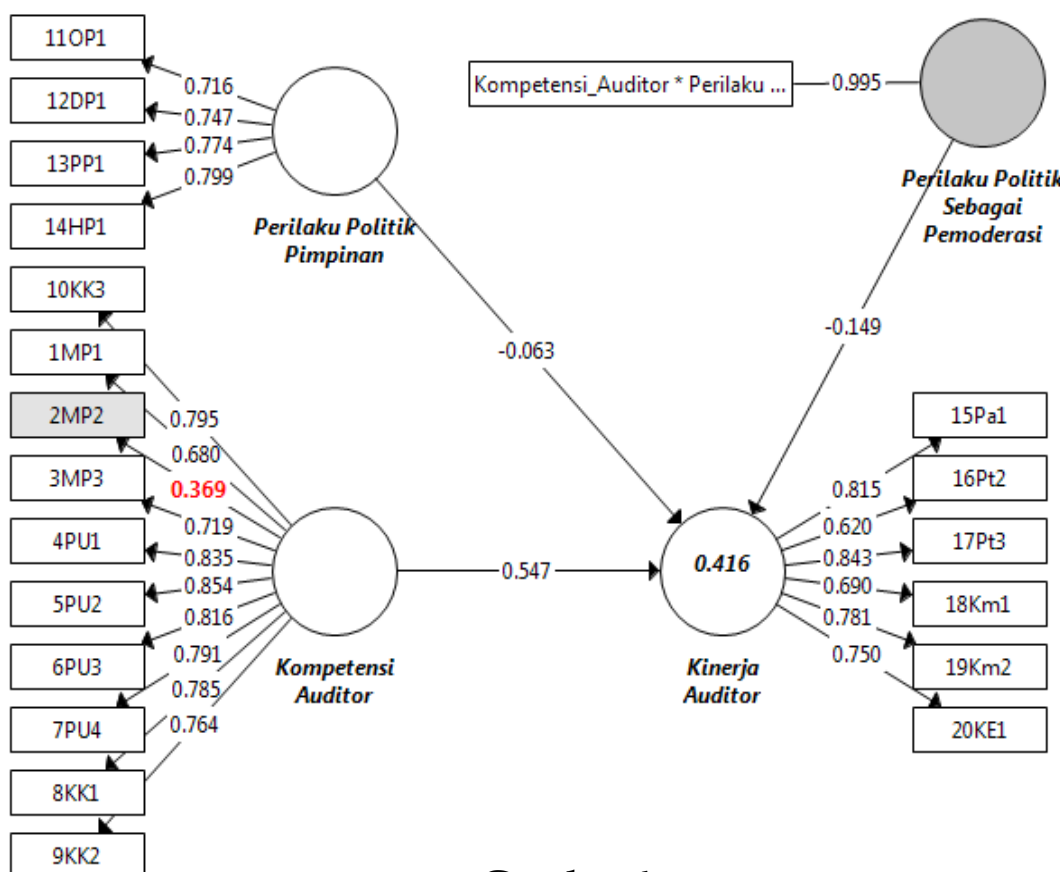

9 KK2

Gambar 4

Model Moderasi Awal 
Tabel 5

Evaluasi Discriminant Validity

\begin{tabular}{|c|c|c|c|c|c|}
\hline \multirow{2}{*}{ Konstruk } & \multicolumn{2}{|c|}{$\begin{array}{l}\text { Model } \\
\text { Mediasi }\end{array}$} & \multicolumn{2}{|r|}{$\begin{array}{c}\text { Model } \\
\text { Moderasi }\end{array}$} & \multirow{2}{*}{ Kesimpulan } \\
\hline & $\begin{array}{l}\text { Akar } \\
\text { AVE }\end{array}$ & Correlation & $\begin{array}{l}\text { Akar } \\
\text { AVE }\end{array}$ & Correlation & \\
\hline $\begin{array}{l}\text { Perilaku politik } \\
\text { pimpinan memoderasi } \\
\text { kompetensi auditor }\end{array}$ & --- & --- & 1,000 & $\begin{array}{c}-0,357 \\
-0,330 ; 0,446\end{array}$ & $\begin{array}{l}\text { Memenuhi evaluasi } \\
\text { discriminat validity }\end{array}$ \\
\hline Kompetensi auditor & 0,785 & 0,$621 ;-0,451$ & 0,785 & $\begin{array}{c}0,624 \\
-0,453 ;-0,330\end{array}$ & $\begin{array}{l}\text { Memenuhi evaluasi } \\
\text { discriminat validity }\end{array}$ \\
\hline $\begin{array}{l}\text { Perilaku politik } \\
\text { pimpinan }\end{array}$ & 0,765 & $\begin{array}{c}-0,370 ;- \\
0,451\end{array}$ & 0,760 & $\begin{array}{c}-0,375 \\
-0,453 ; 0,446\end{array}$ & $\begin{array}{l}\text { Memenuhi evaluasi } \\
\text { discriminat validity }\end{array}$ \\
\hline Kinerja auditor & 0,754 & 0,$621 ;-0,370$ & 0,754 & $\begin{array}{c}0,624 ; \\
-0,375 ;-0,357\end{array}$ & $\begin{array}{l}\text { Memenuhi evaluasi } \\
\text { discriminat validity }\end{array}$ \\
\hline
\end{tabular}

Tabel 6

Evaluasi Composite Reliability

\begin{tabular}{lcccc}
\hline \hline \multirow{1}{*}{ Konstruk } & \multicolumn{2}{c}{$\begin{array}{c}\text { Composite } \\
\text { Reliability }\end{array}$} & $\begin{array}{c}\text { Critical } \\
\text { Value }\end{array}$ & Kesimpulan \\
\cline { 2 - 3 } & $\begin{array}{c}\text { Model } \\
\text { Mediasi }\end{array}$ & $\begin{array}{c}\text { Model } \\
\text { Moderasi }\end{array}$ & & \\
\hline $\begin{array}{l}\text { Perilaku politik pimpinan } \\
\text { memoderasi kompetensi auditor }\end{array}$ & --- & 1,000 & & $\begin{array}{c}\text { Memenuhi evaluasi } \\
\text { composite realiability } \\
\text { Kompetensi Auditor }\end{array}$ \\
Perilaku Politik Pimpinan & 0,935 & 0,935 & $>0,6$ & $\begin{array}{l}\text { Memenuhi evaluasi } \\
\text { composite realiability } \\
\text { Memenuhi evaluasi } \\
\text { composite realiability } \\
\text { Kinerja Auditor }\end{array}$ \\
\hline
\end{tabular}

Sumber: data diolah (2018)

Berdasarkan informasi yang disajikan pada Tabel 6, diketahui semua konstruk yang digunakan pada masing-masing model, memiliki composite reliability lebih besar dari critical value 0,6, sehingga dapat disimpulkan seluruh konstruk telah memenuhi evaluasi composite reliability (relibel).

b) Evaluasi cronbach's alpha

Evaluasi cronbach's alpha, bertujuan untuk derajat konsistensi eksternal yang tidak mengukur unidimensionalitas konstruk. Evaluasi ini dilakukan dengan menganalisa cronbach's alpha konstruk. Suatu konstruk memenuhi evaluasi cronbach's alpha, jika cronbach's alpha konstruk tersebut lebih besar dari critical value 0,6.
Berdasarkan informasi yang disajikan pada Tabel 7, diketahui semua konstruk yang digunakan pada masing-masing model, memiliki cronbach's alpha lebih besar dari critical value 0,6, sehingga dapat disimpulkan seluruh konstruk telah memenuhi evaluasi cronbach's alpha (relibel).

\section{Evaluasi Outer Loadings (Outer Model)}

Evaluasi outer loadings pada outer model merupakan evaluasi terhadap hubungan antara indikator dengan konstruk yang dijelaskannya. Evaluasi ini dilakukan dengan menganalisa outer weights or loadings dan $t$ value antara indikator dengan konstruk yang dijelaskannya. Suatu indikator dapat menjelaskan dengan baik konstruk 
yang dijelaskannya jika memiliki $t$ value lebih besar dari $t$ critical sebesar 2,58 (taraf signifikansi 1\%). Jika evaluasi ini terpenuhi, maka nilai weihgt or loading yang dapat dilihat dari nilai orginal sample dapat digunakan untuk memprediksi suatu konstruk.

Tabel 7

Evaluasi Cronbah's Alpha

\begin{tabular}{|c|c|c|c|c|}
\hline \multirow[b]{2}{*}{ Konstruk } & \multicolumn{2}{|c|}{ Cronbach's Alpha } & \multirow[b]{2}{*}{$\begin{array}{c}\text { Critical } \\
\text { Value }\end{array}$} & \multirow[b]{2}{*}{ Kesimpulan } \\
\hline & $\begin{array}{l}\text { Model } \\
\text { Mediasi }\end{array}$ & $\begin{array}{c}\text { Model } \\
\text { Moderasi }\end{array}$ & & \\
\hline $\begin{array}{l}\text { Perilaku politik pimpinan } \\
\text { memoderasi kompetensi auditor }\end{array}$ & -- & 1,000 & \multirow{4}{*}{$>0,6$} & $\begin{array}{l}\text { Memenuhi evaluasi } \\
\text { cronbach's alpha }\end{array}$ \\
\hline Kompetensi Auditor & 0,921 & 0,923 & & $\begin{array}{l}\text { Memenuhi evaluasi } \\
\text { cronbach's alpha }\end{array}$ \\
\hline Perilaku Politik Pimpinan & 0,805 & 0,840 & & $\begin{array}{l}\text { Memenuhi evaluasi } \\
\text { cronbach's alpha }\end{array}$ \\
\hline Kinerja Auditor & 0,848 & 0,871 & & $\begin{array}{l}\text { Memenuhi evaluasi } \\
\text { cronbach's alpha }\end{array}$ \\
\hline
\end{tabular}

Sumber: data diolah (2018)

Tabel 8

Evaluasi Outer Loadings

\begin{tabular}{|c|c|c|c|c|c|c|c|c|}
\hline \multirow{2}{*}{ Keterangan } & \multicolumn{4}{|c|}{$\begin{array}{c}\text { Model } \\
\text { Mediasi }\end{array}$} & \multicolumn{4}{|c|}{$\begin{array}{c}\text { Model } \\
\text { Moderasi }\end{array}$} \\
\hline & $\begin{array}{l}\text { Original } \\
\text { Sample }\end{array}$ & $\begin{array}{c}\text { Standard } \\
\text { Deviation }\end{array}$ & $\begin{array}{c}T \\
\text { Statistics }\end{array}$ & $\begin{array}{c}P \\
\text { Values }\end{array}$ & $\begin{array}{l}\text { Original } \\
\text { Sample }\end{array}$ & $\begin{array}{c}\text { Standard } \\
\text { Deviation }\end{array}$ & $\begin{array}{c}T \\
\text { Statistics }\end{array}$ & $\begin{array}{c}P \\
\text { Values }\end{array}$ \\
\hline \multicolumn{9}{|c|}{ Kompetensi Auditor: } \\
\hline $1 \mathrm{MP1}$ & 0.664 & 0.057 & 11.627 & 0.000 & 0.675 & 0.054 & 12.531 & 0.000 \\
\hline 3MP3 & 0.731 & 0.035 & 20.829 & 0.000 & 0.721 & 0.038 & 19.021 & 0.000 \\
\hline 4PU1 & 0.840 & 0.026 & 32.736 & 0.000 & 0.837 & 0.026 & 31.739 & 0.000 \\
\hline 5PU2 & 0.859 & 0.024 & 35.811 & 0.000 & 0.855 & 0.025 & 33.642 & 0.000 \\
\hline 6PU3 & 0.816 & 0.029 & 28.236 & 0.000 & 0.816 & 0.028 & 29.474 & 0.000 \\
\hline 7PU4 & 0.790 & 0.034 & 23.175 & 0.000 & 0.793 & 0.033 & 24.244 & 0.000 \\
\hline $8 \mathrm{KK} 1$ & 0.789 & 0.045 & 17.663 & 0.000 & 0.787 & 0.046 & 17.139 & 0.000 \\
\hline $9 \mathrm{KK} 2$ & 0.764 & 0.032 & 24.234 & 0.000 & 0.767 & 0.032 & 24.310 & 0.000 \\
\hline $10 \mathrm{KK} 3$ & 0.797 & 0.032 & 25.141 & 0.000 & 0.798 & 0.031 & 25.631 & 0.000 \\
\hline \multicolumn{9}{|c|}{ Perilaku Politik Pimpinan: } \\
\hline 11OP1 & 0.701 & 0.085 & 8.266 & 0.000 & 0.715 & 0.114 & 6.256 & 0.000 \\
\hline 12DP1 & 0.761 & 0.126 & 6.056 & 0.000 & 0.748 & 0.172 & 4.358 & 0.000 \\
\hline 13PP1 & 0.785 & 0.118 & 6.657 & 0.000 & 0.774 & 0.167 & 4.648 & 0.000 \\
\hline 14HP1 & 0.808 & 0.100 & 8.055 & 0.000 & 0.799 & 0.146 & 5.486 & 0.000 \\
\hline \multicolumn{9}{|c|}{ Kinerja Auditor: } \\
\hline $15 \mathrm{~Pa} 1$ & 0.816 & 0.030 & 27.615 & 0.000 & 0.816 & 0.028 & 28.941 & 0.000 \\
\hline $16 \mathrm{Pt} 2$ & 0.619 & 0.070 & 8.852 & 0.000 & 0.620 & 0.070 & 8.817 & 0.000 \\
\hline $17 \mathrm{Pt} 3$ & 0.843 & 0.028 & 30.201 & 0.000 & 0.843 & 0.027 & 31.566 & 0.000 \\
\hline $18 \mathrm{Km} 1$ & 0.688 & 0.062 & 11.170 & 0.000 & 0.688 & 0.058 & 11.789 & 0.000 \\
\hline $19 \mathrm{Km} 2$ & 0.781 & 0.035 & 22.337 & 0.000 & 0.780 & 0.033 & 23.619 & 0.000 \\
\hline 20KE1 & 0.751 & 0.036 & 20.653 & 0.000 & 0.751 & 0.035 & 21.713 & 0.000 \\
\hline
\end{tabular}

Sumber: data diolah (2018)

Berdasarkan informasi yang disajikan pada Tabel 8 , diketahui semua item per- tanyaan yang digunakan untuk menjelaskan indikator-indikator konstruk, memiliki $t$ 
value lebih besar dari $t$ critical 2,58, sehingga dapat disimpulkan semua item pertanyaan yang digunakan untuk meng- ukur indikator konstruk, dapat menjelaskan konstruknya dengan baik.

\section{Analisis Inner Model}

Analisis inner model yang terdiri atas: evaluasi kontribusi $\left(R^{2}\right)$, evaluasi substantif $\left(\mathrm{f}^{2}\right)$, evaluasi prediksi relevansi $\left(\mathrm{Q}^{2}\right)$, dan evaluasi path coefficients, yang akan diuraikan sebagai berikut:

\section{Evaluasi $R$ Square $\left(R^{2}\right)$}

Evaluasi $R$ Square $\left(R^{2}\right)$ digunakan untuk mengetahui seberapa besar kontribusi satu atau beberapa variabel independen dapat menjelaskan variabel dependen yang diprediksinya. Satu atau lebih variabel independen dikatakan dapat berkontribusi secara "baik" jika $\mathrm{R}^{2}$ lebih besar dari critical value 0,67 , "moderat" lebih besar dari critical value 0,33, dan "lemah" lebih besar dari critical value 0,19 (Ghozali, 2016).

Tabel 9

Evaluasi $R$ Square $\left(R^{2}\right)$

\begin{tabular}{lcccc}
\hline \hline \multicolumn{1}{c}{ Keterangan } & $\begin{array}{c}\text { Model } \\
\text { Mediasi }\end{array}$ & $\begin{array}{c}\text { Model } \\
\text { Moderasi }\end{array}$ & $\begin{array}{c}\text { Critical } \\
\text { Value }\end{array}$ & Kesimpulan \\
\hline $\begin{array}{l}\text { Kontribusi perilaku politik pim- } \\
\text { pinan, kompetensi auditor, dan }\end{array}$ & & & \\
kompetensi auditor setelah di- & -- & 0.42 & "baik" jika $\mathrm{R}^{2}$ & $\begin{array}{c}\text { Moderat } \\
\text { mendekati } \\
\text { baik }\end{array}$ \\
$\begin{array}{l}\text { moderasi oleh perilaku perilaku } \\
\text { politik pimpinan terhadap kinerja }\end{array}$ & & $\begin{array}{c}\text { "moderat" jika } \\
\text { auditor }\end{array}$ & $\mathrm{R}^{2}>0,33 ;$ & \\
$\begin{array}{l}\text { Kontribusi kompetensi auditor, } \\
\text { perilaku politik pimpinan, dan } \\
\text { perilaku politik pimpinan setelah } \\
\text { dimediasi dengan kompetensi }\end{array}$ & 0.396 & $-\mathrm{R}^{2}$ jika & Moderat \\
auditor terhadap kinerja auditor. & & & $>0,19$ & $\begin{array}{c}\text { mendekati } \\
\text { baik }\end{array}$ \\
\hline
\end{tabular}

Sumber: data diolah (2018)

Berdasarkan informasi yang disajikan pada Tabel 9, diketahui pada model mediasi, ketiga konstruk independen terhadap konstruk dependen kinerja auditor memiliki $R$ Square 39,6\% sehingga model dapat diinterprestasikan "moderat mendekati baik". Sedangkan, pada model moderasi, keempat konstruk independen terhadap konstruk dependen kinerja auditor memiliki $R$ Square $42,0 \%$ sehingga model ini juga dapat diinterprestasikan "moderat mendekati baik".

\section{Evaluasif Square ( $\left.f^{2}\right)$}

Evaluasif Square $\left(f^{2}\right)$ merupakan evaluasi yang menjelaskan seberapa substantifnya masing-masing variabel independen terhadap variabel dependennya, sehingga variabel independen tersebut layak dimasukkan dalam model. Sebuah variabel independen dikatakan memiliki tingkat substantif "lemah" jika $\mathrm{f}^{2}$ lebih dari critical value 0,02 , "medium" jika $\mathrm{f}^{2}$ lebih dari critical value 0,15 , dan "besar" jika $\mathrm{f}^{2}$ lebih dari critical value 0,35 (Ghozali, 2016).

Berdasarkan informasi yang disajikan pada Tabel 10, diketahui baik pada model mediasi maupun moderat, dari tiga konstruk independen yang digunakan untuk memprediksi kinerja auditor, hanya konstruk perilaku politik pimpinan yang tidak memiliki substansi karena memiliki $f$ square 0,005 dan 0,017 (kurang dari 0,02). Ketidak substantifan perilaku politik pimpinan dalam memprediksi kinerja auditor, mendukung dua model yang diajukan dimana konstruk tersebut diduga perlu dimediasi 
untuk menjelaskan kinerja auditor, maupun bertindak sebagai konstruk pemoderasi yang dapat menjelaskan kompetensi auditor sehubungan dengan kinerja auditor.

\section{Evaluasi $Q$ Square $\left(Q^{2}\right)$}

Evaluasi $Q$ Square merupakan evaluasi dalam menjelaskan seberapa baik nilai obervasi yang dihasilkan oleh sebuah model serta estimasi parameternya (variabel independen) sehingga relevan untuk diprediksi. Sebuah model dikatakan memiliki relevansi prediksi jika memiliki $\mathrm{Q}^{2}$ dengan rentang $0>Q^{2}>1$ (Ghozali, 2016). Dalam smartPLS evaluasi $Q$ Square dilakukan dengan prosedur blindfolding.

Tabel 10

Evaluasi $f$ Square $\left(f^{2}\right)$

\begin{tabular}{|c|c|c|c|c|}
\hline Keterangan & $\begin{array}{c}\text { Model } \\
\text { Mediasi }\end{array}$ & $\begin{array}{c}\text { Model } \\
\text { Moderasi }\end{array}$ & $\begin{array}{c}\text { Critical } \\
\text { Value }\end{array}$ & Kesimpulan \\
\hline Variabel dependen "Kinerja Audtor": & & & \multirow{9}{*}{$\begin{array}{c}\text { "besar" jika f2 } \\
\geq 0,35 ; \\
\text { "medium" } \\
\text { jika f2 } 20,15 \\
\text { "lemah" jika } \\
\text { f2 } \\
\geq 0,02\end{array}$} & \\
\hline Perilaku politik pimpinan & & & & tidak substantif \\
\hline Kompetensi auditor & --- & 0.005 & & besar \\
\hline Perilaku politik pimpinan memoderasi & --- & 0.397 & & lemah \\
\hline kompetensi auditor & --- & 0.030 & & mendekati \\
\hline “Kompetensi & & & & $\begin{array}{l}\text { medium } \\
\text { medium }\end{array}$ \\
\hline $\begin{array}{l}\text { Auditor": } \\
\text { Perilak" nolitik nimninan }\end{array}$ & 0.255 & --- & & menekati besar \\
\hline Variabel dependen "kinerja Auditor": & 0.017 & --- & & \\
\hline $\begin{array}{l}\text { Perilaku politik pimpinan } \\
\text { Kompetensi audtor }\end{array}$ & 0.429 & --- & & $\begin{array}{l}\text { tidak substantif } \\
\text { besar }\end{array}$ \\
\hline
\end{tabular}

Sumber: data diolah (2018)

Tabel 11

Evaluasi $Q$ Square $\left(Q^{2}\right)$

\begin{tabular}{|c|c|c|c|c|}
\hline Keterangan & $\begin{array}{c}\text { Model } \\
\text { Mediasi }\end{array}$ & $\begin{array}{c}\text { Model } \\
\text { Moderasi }\end{array}$ & $\begin{array}{c}\text { Critical } \\
\text { Value }\end{array}$ & Kesimpulan \\
\hline $\begin{array}{l}\text { Variabel dependen "Kinerja Audtor": } \\
\text { Perilaku politik pimpinan } \\
\text { Kompetensi auditor } \\
\text { Perilaku politik pimpinan } \\
\text { memoderasi kompetensi auditor } \\
\text { Variabel dependen "kompetensi } \\
\text { auditor": } \\
\text { Perilaku politik pimpinan } \\
\text { Variabel dependen "Kinerja Auditor": } \\
\text { Perilaku politik pimpinan } \\
\text { Kompetensi audtor }\end{array}$ & 0,118 & 0,210 & $\begin{array}{c}\text { “memiliki } \\
\text { relevansi } \\
\text { prediksi” jika } \\
\mathrm{Q}^{2} \neq 0, \\
\text { “tidak } \\
\text { memiliki } \\
\text { relevansi } \\
\text { prediksi” jika } \\
\mathrm{Q}^{2}=0\end{array}$ & $\begin{array}{l}\text { Memenuhi } \\
\text { evaluasi relevansi } \\
\text { prediksi } \\
\text { Memenuhi } \\
\text { evaluasi relevansi } \\
\text { prediksi } \\
\text { Memenuhi } \\
\text { evaluasi relevansi } \\
\text { prediksi } \\
\end{array}$ \\
\hline
\end{tabular}

Sumber: data diolah (2018)

Berdasarkan informasi yang disajikan pada Tabel 11, diketahui dalam model mediasi variabel independen perilaku politik pimpinan, dan kompetensi auditor cukup relevan dalam memprediksi kinerja auditor dengan $Q^{2}$ sebesar 0,203 . Selain itu, model mediasi juga didukung dengan cukup relevannya perilaku politik pimpinan dalam memprediksi kompetensi, dimana kompetensi sebagai variabel mediasi terhadap kinerja dengan $Q^{2}$ sebesar 0,118. Sama halnya dengan model mediasi, pada model mode- 
rasi semua variabel independen yang terdiri atas: perilaku politik pimpinan, kompetensi auditor, dan perilaku politik pimpinan memoderasi kompetensi auditor dalam cukup relevan dalam mem prediksi kinerja auditor dengan $Q^{2}$ sebesar 0,210. Sehingga dapat disimpulkan kedua model yang diajukan layak dalam memprediksi kinerja auditor.

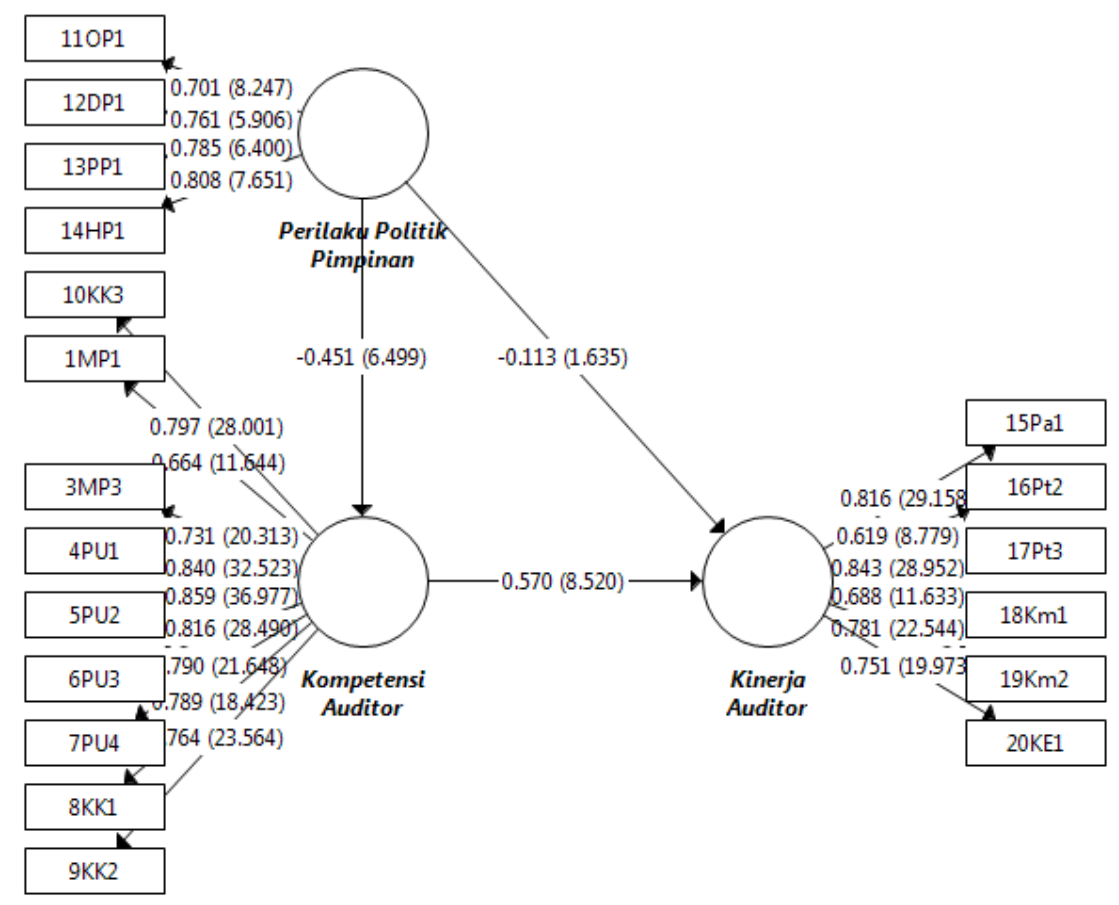

Gambar 5

Model Mediasi Akhir

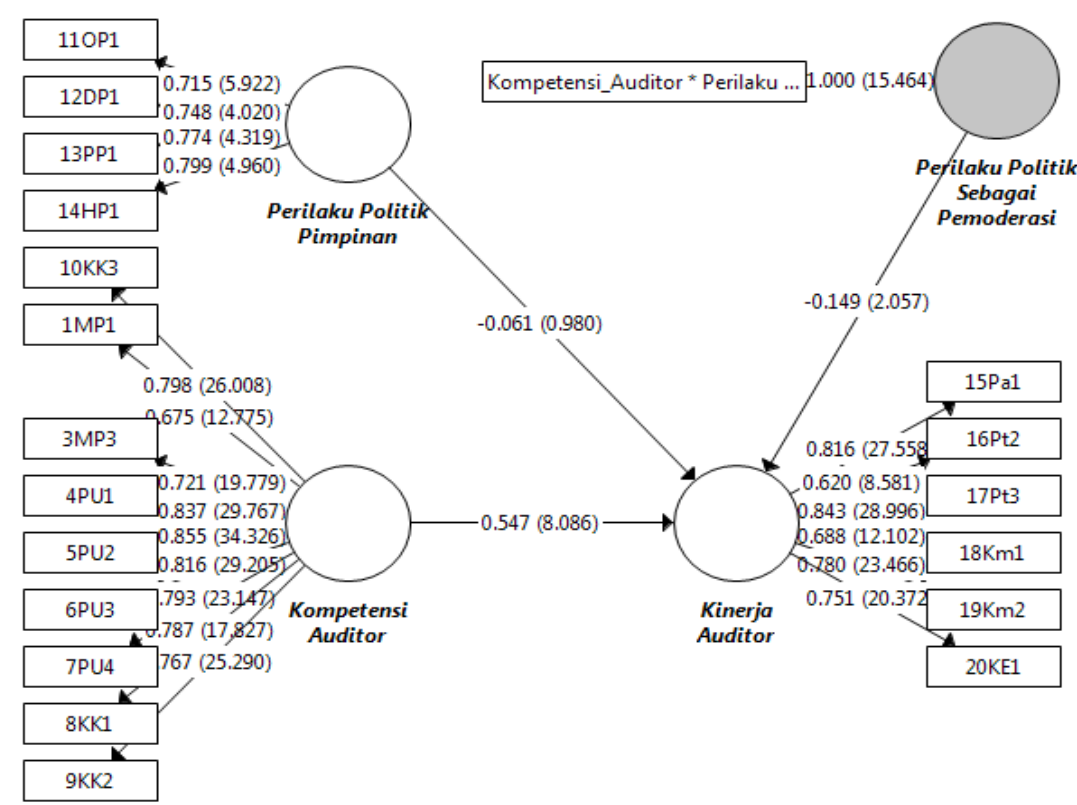

Gambar 6

Model Moderasi Akhir 


\section{Evaluasi Estimasi Path Coefficients}

Evaluasi estimasi path coefficients merupakan evaluasi untuk mengetahui seberapa baik hubungan kausalitas masingmasing konstruk independen terhadap konstruk dependennya yang diprediksi dalam model. Suatu variabel independen dikatakan memiliki hubungan kausalitas yang baik, jika memiliki $t_{\text {statitik }}$ lebih daricritical value sebesar 2,58 (untuk taraf signi fikansi 1\%), 1,96 (untuk taraf signifikansi 5\%), dan 1,65 (untuk taraf signifikansi 10\%).
Evaluasi estimasi path coefficient dalam penelitian ini, menggunakan smartPLS dengan prosedur bootstrapping. Hasil evaluasi estimasi path coefficient selanjut digunakan sebagai dasar pengambilan keputusan dalam pengujian hipotesis.

Visualisasi model akhir mediasi dan moderasi yang disertai path coefficients dan $\mathrm{t}_{\text {statistik }}$ dengan prosedur bootstrapping SmartPLS sampai 500 iterasi, masing-masing ditunjukan dengan Gambar 5 dan Gambar 6.

Tabel 12

Evaluasi Path Coefficients

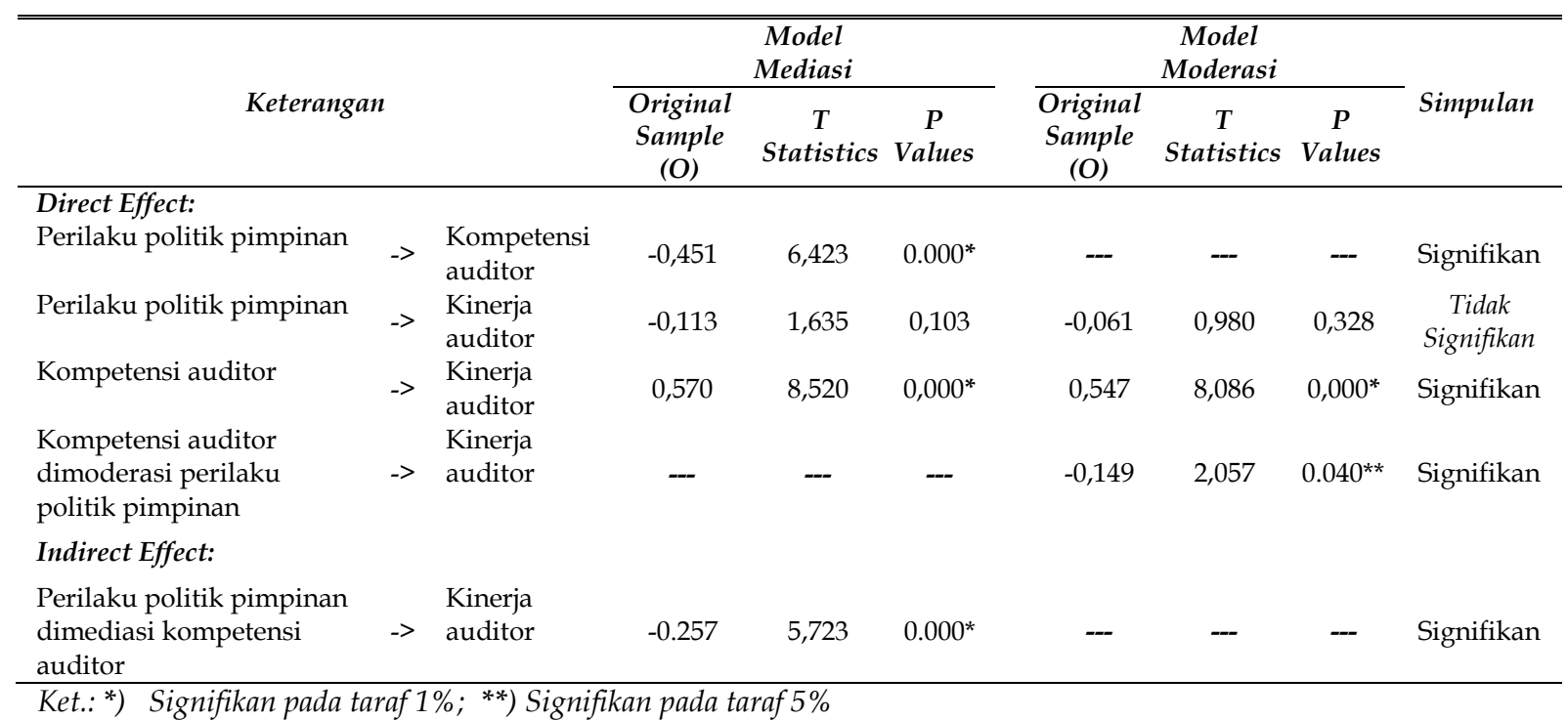

Sumber: data diolah (2018)

Berdasarkan informasi yang disajikan pada Tabel 12, dapat dijelaskan sebagai berikut: Pertama, dalam model mediasi yang mengukur pengaruh langsung (direct effect) dan pengaruh tidak langsung (indirect effect). Pada pengukuran pengaruh langsung, pengaruh perilaku politik pimpinan terhadap kinerja auditor memiliki nilai koefisien jalur sebesar $-0,113$ dengan $t_{\text {statistik }}$ sebesar 1,635 ( $<1,65$ dengan taraf signifikansi 10\%). Maka dapat dikatakan perilaku politik pimpinan tidak berpengaruh langsung terhadap kinerja auditor meskipun arahnya negatif. Sedangkan, dalam pengukuran pengaruh tidak langsung, pengaruh perilaku politik pimpinan terhadap kinerja auditor setelah dimediasi dengan kompetensi auditor memiliki koefisien jalur sebesar $-0,257$ dengan $t_{\text {statistik }}$ sebesar 5,723 (>2,58 dengan taraf signifikansi 1\%). Maka dapat dikatakan perilaku politik pimpinan berpengaruh signifikan negatif terhadap kinerja auditor setelah dimediasi dengan kompetensi auditor. Kedua, dalam model moderasi yang mengukur pengaruh langsung (direct effect) dan pengaruh setelah dimoderasi (moderating effect). Pada pengukuran pengaruh langsung, pengaruh perilaku politik pimpinan terhadap kinerja auditor memiliki koefisien jalur sebesar $-0,061$ dengan $t_{\text {statistik }}$ sebesar 0,980 (<1,65 dengan taraf signifikansi $10 \%)$. Maka dapat dikatakan perilaku politik 
pimpinan tidak berpengaruh langsung terhadap kinerja meskipun arahnya negatif. Sedangkan, pada pengukuran pengaruh moderasi, pengaruh perilaku politik pimpinan terhadap kinerja auditor setelah memoderasi kompetensi auditor memiliki koefisien jalur sebesar -0,149 dengan $t_{\text {statistik }}$ sebesar 2,057 (>1,96 dengan taraf signifkansi $5 \%)$. Maka dapat dikatakan perilaku politik pimpinan berpengaruh signifikan negatif terhadap kinerja auditor setelah memoderasi kompetensi auditor.

\section{Pembahasan}

Pengaruh Perilaku Politik Pimpinan terhadap Kinerja Auditor setelah dimediasi Kompetensi Auditor

Hasil analisis menunjukkan bahwa perilaku politik pimpinan tidak berpengaruh terhadap kinerja auditor, melainkan berpengaruh negatif melalui kompetensi auditor. Maka dapat dikatakan kompetensi auditor sebagai pure mediation pengaruh perilaku politik pimpinan terhadap kinerja auditor. Hal ini mengindikasikan perilaku politik pimpinan merupakan faktor pemicu turunnya kompetensi auditor. Semakin tinggi perilaku politik pimpinan menyebabkan semakin rendahnya pengimplementasian kompetensi yang dimiliki auditor yang pada akhirnya penurunan kompetensi tersebut diikuti dengan semakin rendahnya kinerja auditor. Pengaruh Perilaku Politik Pimpinan terhadap Kinerja Auditor setelah memoderasi Kompetensi Auditor

Hasil analisis menunjukkan bahwa perilaku politik pimpinan tidak berpengaruh terhadap kinerja auditor, melainkan berpengaruh negatif setelah berinteraksi dengan kompetensi auditor. Maka dapat dikatakan perilaku politik pimpinan sebagai pure moderation pengaruh kompetensi auditor terhadap kinerja auditor.

Hal ini mengindikasikan perilaku politik pimpinan merupakan faktor yang dapat memperlemah pengimplementasian kompetensi yang dimiliki oleh auditor, yang pada akhirnya akan diikuti dengan penurunan kinerja auditor.

\section{SIMPULAN DAN SARAN Simpulan}

Berdasarkan hasil penelitian berkaitan dengan dua model yang diajukan, maka dapat disimpulkan sebagai berikut: pertama, pada model mediasi perilaku politik pimpinan berpengaruh negatif terhadap kinerja auditor setelah dimediasi kompetensi auditor, dan kedua, pada model moderasi perilaku politik pimpinan berpengaruh negatif terhadap kinerja auditor setelah memoderasi (memperlemah) kompetensi auditor. Kedua hasil penelitian tersebut membuktikan pentingnya untuk menekan atau mengurangi aspek perilaku politik pimpinan, disamping peningkatan aspek kompetensi auditor untuk peningkatan kinerja auditor dalam rangka penguatan fungsi early warning system Inspektorat Kabupaten atau Kota di Jawa Barat.

\section{Keterbatasan dan Saran}

Berdasarkan penelitian yang telah dilakukan terdapat keterbatasan pada penelitian ini, antara lain: Pertama, penelitian hanya dilakukan pada auditor pemerintah yang ada di inspektorat kabupaten atau kota yang ada di Jawa Barat, sehingga pada penelitian yang akan datang dapat menggunakan obyek auditor internal lain, seperti: inspektorat kabupaten atau kota lain, inspektorat provinsi, inspektorat jenderal, dan BPKP maupun auditor eksternal pemerintah yang ada di BPK. Kedua, penelitian hanya dilakukan pada auditor pemerintah, sehingga pada penelitian yang akan datang dapat menggunakan auditor internal yang bekerja pada perusahaan swasta yang profit oriented maupun auditor eksternal yang bekerja pada KAP.

\section{DAFTAR PUSTAKA}

ACCH-KPK. 2017. Gratifikasi Berdasarkan Wilayah. Retrieved from Anti Corruption Clearing House: https://acch.kpk. go.id/id/statistik/gratifikasi/gratifikas i-berdasarkan-wilayah.

Ahearn, K. K., Ferris, G. R., Hochwarter, A. W., Douglas, C., dan Ammeter, P. A. 
2004. Leader Political Skill and Team Performance. Journal of Management 30(3): 309-327.

Alim, M. N., Hapsari, T., dan Purwanti, L. 2007. Pengaruh Kompetensi dan Independensi terhadap Kualitas Audit dengan Etika Auditor Sebagai Variabel Moderasi. Prosiding Simposium Nasional Akuntansi V Semarang: 1-26.

Andrianti, G. T., Herawati, N. T., dan Purnamawati, I. 2016. Pengaruh Kompetensi, Independensi, dan Komitmen Organisasi Auditor terhadap Kinerja Auditor (Studi pada Tiga Inspektorat di Provinsi Bali). Jurnal Ilmiah Mahasiswa Akuntansi Undiksa 4(1): 1-12.

Boddewyn, J. J., dan Brewer, T. L. 1994. International Bussiness Political Behavior: New Theoritical Directions. Academy oi Management Review 19(1): 119143.

Bodla, M. A., Afza, T., dan Danish, R. Q. 2014. Relationship between Organizational Politics Perceptions and Employees' Performance; Mediating Role of Social Exchange Perceptions. Pakistan Journal of Commerce and Social Sciences 8(2): 426- 444.

Buchanan, D. A. 2008. You Stab My Back, I'll Stab Yours: Management Experience and Perceptions of Organization Politi cal Behaviour. British Journal of Management 19(1): 49-64.

Chandrarin, G. 2017. Metode Riset Akuntansi. Salemba Empat. Jakarta.

Christina, dan Melinda. 2012. Pengaruh Indepencensi dan Kompetensi Auditor terhadap Kinerja Auditor Eksternal (Studi Kasus KAP Bandung). Universitas Kristen Maranatha.

Cropanzano, R., dan Mitchell, S. M. 2005. Social Exchange Theory: An Interdisciplinary Review. Journal of Management 31: 874-900.

Ferdinand, A. 2014. Metode Penelitian Manajemen: Pedoman Penelitian untuk Penulisan Skripsi, Tesis, dan Disertasi Ilmu Manajemen. Badan Penerbit Universitas Diponegoro. Semarang.
Fernanda, F. 2018. Pengaruh independensi, profesionalisme, dan kompetensi terhadap kinerja auditor pada Kantor Akuntan Publik di Surabaya. Widya Mandala Chatolic University Surabaya.

Ghozali, I. 2014. Structural Equation Modeling: Metode Alternatif dengan Partial Least Squares (PLS). Badan Penerbit Universitas Diponegoro. Semarang.

Ghozali, I. 2016. Desain Penelitian Kuantitatif dan Kualitatif: Untuk Akuntansi, Bisnis dan Ilmu Sosial Lainnya. Yoga Pratama. Semarang.

Gibson, J. L., Donnely, J. H., dan Ivancevich, J. M. 1996. Organisasi: Perialaku, Proses, Struktur Jilid I. Binarupa Aksara. Jakarta. Jafarani, H., Mortazavi, S., Nazemi, S., dan Bull, P. 2012. Political behavior in organizational context: nature, research and paradigm. Management Science Letters (2): 2987-3000.

Laana, A., Sulindawati, E. N., dan Sinarwati, N. 2015. Pengaruh Integritas, Objektivitas, Kerahasiaan, Kompetensi Auditor, Profesionalisme Auditor, dan Sensitivitas Etika Profesi terhadap Kinerja Auditor Inspektorat Kota Singaraja dan Kota Gianyar. Jurnal Ilmiah Mahasiswa Akuntansi Undiksa 3(1): 1-12.

Mangkunegara, A. P. 2005. Evaluasi Kinerja SDM. Refika Aditama. Bandung.

Marganingsih, A., dan Martani, D. 2010. Anteseden Komitmen Organisasi dan Motivasi: Konsekuensinya terhadap Kinerja Auditor Intern Pemerintah. Jurnal Akuntansi dan Keuangan Indonesia 7(1): 79-108.

Moorman, R. H., dan Blakely, G. L. 1995. Individualism-collectivism as an individual difference predictor of organizational citizenship behavior. Journal of Organization Behavior 16: 127-142.

Permatasari, F. A., Sulindawati, N., dan Sudjana, E. 2016. Pengaruh Komitmen Profesi, Integritas, Objektivitas, Kompetensi, dan Perilaku Profesional terhadap Kinerja Auditor (Studi Empiris pada Inspektorat Pemerintah Provinsi Bali, Kabupaten Bangli, dan Kabupaten 
Klungkung). Jurnal Ilmiah Mahasiswa Akuntansi Undiksa 4(1): 1-12.

Randall, M. L., Crozpanzano, R., Bormann, C. A., dan Birjulin, A. 1999. Organizational politics and organizational support as predictors of work attitudes, job performance, and organizational citizenship behavior. Journal of Organizational Behavior (20): 159-174.

Salju, Rismawati, dan Bachtiar, M. D. 2014. Pengaruh Kompetensi dan Independensi terhadap Kinerja Auditor Pemerintah Kabupaten Luwu Timur. Jurna Equilibrium 4(2): 100-123.

Soedarsa, H. G., Mahlinda, A. R., dan Riswan. 2012. Pengaruh Komitmen Organisasi dan Kompetensi Auditor terhadap Kinerja Auditor Kantor Inspektorat Daerah Provinsi Lampung (Study Kasus pada Kantor Inspektorat Daerah Provinsi Lampung). JURNAL Akuntansi dan Keuangan 3(2): 169-184.

Sugiyono. 2014. Metode Penelitian Kombinasi (Mixed Methods). Alpabeta. Bandung.

Sukriah, I., Akram, dan Inapaty, B. A. 2009. Pengaruh Pengalaman Kerja, Independensi, Objektivitas, Integritas dan Kompetensi terhadap Kualitas Hasil Pemeriksaan. Prosiding Simposium Nasional Akuntansi XII Palembang: 1-10.
Trisnaningsih, S. 2007. Independensi Auditor dan Komitmen Organisasi sebagai Mediasi Pengaruh Pemahaman Good Governance, Gaya Kepemimpinan, dan Budaya Organisasi terhadap Kinerja Auditor. Prosiding Simposium Nasional Akuntansi X Makassar: 1-56.

Walumbwa, F. O., dan Lawler, J. J. 2003. Building effective organizations: transformational leadership, collectivist orientation, work-related attitudes and withdrawal behaviours in three emerging economies. International Journal of Human Resource Management: 1083-1101.

Wijaya, M., dan Suryadinata. 2012. Pengaruh Kompetensi serta Pengalaman Auditor Kinerja Auditor. UPN Veteran Yogyakarta.

Willauer, B. 2005. Consensus as a Key Success Factor in Strategy Making. Wiesbaden: 204-206.

Yadnya, P. I., dan Ariyanto, D. 2017. Pengaruh Independensi dan Kompetensi pada Kinerja Auditor dengan Etika Auditor sebagai Variabel Moderasi. EJurnal Akuntansi Universitas Udayana, 9(2): 973-999. 